Review Article

\title{
New Developments in Carbon-Based Nanomaterials for Automotive Brake Pad Applications and Future Challenges
}

\author{
Senthil Kumaran Selvaraj $\mathbb{D}^{1},{ }^{1}$ Rathan Ramesh ${ }^{(D)},{ }^{2}$ Tharun M. V. Narendhra ${ }^{(D)}{ }^{2}$ \\ Ishan Nilesh Agarwal $\left(\mathbb{D},{ }^{2}\right.$ Utkarsh Chadha $\mathbb{D}^{2}{ }^{2}$ Velmurugan Paramasivam $\left(\mathbb{D},{ }^{3}\right.$ \\ and Ponnusamy Palanisamy $\mathbb{D i}^{2}$ \\ ${ }^{1}$ Department of Manufacturing Engineering, School of Mechanical Engineering (SMEC), Vellore Institute of Technology (VIT), \\ Vellore, Tamil Nadu 632014, India \\ ${ }^{2}$ School of Mechanical Engineering, Vellore Institute of Technology (VIT), Vellore 632014, India \\ ${ }^{3}$ School of Mechanical and Automotive Engineering, College of Engineering and Technology, Dilla University, P.O. Box 419, \\ Dilla, Ethiopia
}

Correspondence should be addressed to Senthil Kumaran Selvaraj; senthilkumaran.s@vit.ac.in and Velmurugan Paramasivam; drvelmuruganp@du.edu.et

Received 17 September 2021; Revised 15 October 2021; Accepted 5 November 2021; Published 22 November 2021

Academic Editor: Ibrahim Alarifi

Copyright (C) 2021 Senthil Kumaran Selvaraj et al. This is an open access article distributed under the Creative Commons Attribution License, which permits unrestricted use, distribution, and reproduction in any medium, provided the original work is properly cited.

\begin{abstract}
The proper functioning of automotive brake pads is of utmost importance to ensure the safety of passengers. Therefore, brake pad materials must be chosen with utmost precision and care to ensure their optimal functioning for long durations. Through a thorough literature review, it is found that the materials used currently for this purpose pose multiple discrepancies. Therefore, it is imperative to shift our focus towards nanomaterials, as they are one of the essential novel materials in this field. This study discusses the multiple constituents used in commercial brake pads, their role in improving and stabilizing their operation, and their desired properties to achieve optimal functioning. Parallelly, this study also reviews some of the potential organic and carbon nanomaterials that could prove to provide tough competition to currently utilized materials for brake pad applications. From this review, the major future commercial brake pad materials obtained include the likes of banana peel powder, crab shell powder, coconut fibers, stark corn fibers, metal oxide composites, metal nitride composites, multiwalled carbon nanotubes, and hybrid nanocomposites. These materials are studied on the basis of their performance under high-frictional force applications and analyzed by considering their mechanical, chemical, thermal, and tribological properties. Carbon nanotube-based composites showed improved tribological and braking performances making them more attractive than the materials in commercially available brake pads. In addition to these, the effects of usage of such nanomaterials on the environment and health are reviewed, in order to understand the feasibility of utilization of nanomaterials in automotive brake pad applications. From this analysis, this work suggests that there are a variety of nanomaterials that prove to be capable of automotive brake pad applications and, with further research and technological developments, would prove to be an asset to the automotive brake pad industry.
\end{abstract}

\section{Introduction}

The most integral part of any automotive system is the braking system. The vital component of the braking system is the brake pad. Much progress has been made to improve the performance of the brake pad. The material of the brake pad is the area in which these advancements are made. Brake pads are composites containing constituents such as reinforcements, abrasives, fillers, and solid lubricants [1]. Due to their excellent mechanical properties and high wear resistance, metal matrix composites (MMCs) are generally encouraging for tribological applications [2]. The pads usually consist of asbestos, semimetallic, nonasbestos organic (NAO), and low-steel, low-carbon materials [3]. Among 
the brake pad constituents, fibers are further classified into natural and synthetic fibers based on their availability and unavailability as readymade raw materials from nature. Natural fibers are available at low cost and also are biodegradable. On the other hand, synthetic fibers like asbestos are known for their carcinogenic effects [4]. Similarly, fillers are also classified into two categories, i.e., organic and inorganic fillers [5]. Organic fillers include cashew and rubber dust while inorganic fillers include mica, barium sulfate, and calcium carbonate.

The composite brake friction materials need to satisfy several significant criteria, such as providing constant friction, high wear resistance, less noise, and damping at a wide range of temperatures, pressures, and velocities [6]. To obtain the optimal braking efficiency and functionality, the transformation of relatively more extensive brake pad constituents into the nanocrystalline third body is of utmost importance [7]. Konada and Sai studied the damping characteristics utilizing different surface treatment techniques on carbon fiber (CF) [8]. The results showed that multiwalled carbon nanotubes (MWCNTs) grafted on surface-treated CF (3wt\%) showed good damping behavior and have the potential of minimizing squeal generation during braking.

Macías et al. aimed to determine the presence of diffused oxygen through the brake pad with the help of iron sulfide [9]. The diffusion of oxygen is not desirable for the brake pad as it can cause instability. This study shows how the composite resin starts to decompose and the role of reactive compounds in stabilizing the matrix by reducing the diffusion of oxygen in the pads. This helps to improve the stability of the coefficient of friction of the pads at high temperatures. Qingrui et al. investigated the nonuniform wear and shorter lifespan of sizable nonasbestos brake pads. The brake pad was modeled and simulated on the ADINA software, and simulations were carried out to find the effects of radius, pressure, velocity, and temperature on the wear characteristics of the pads [10]. Results showed that the nonuniform distribution of temperatures and contact forces leads to uneven surface wear of the pads, thereby reducing the stability of the brake pads. Ma et al. analyzed the braking performance of powder metallurgy- (PM-) based iron and copper pads that are mated with carbon fiber-reinforced carbon and silicon carbide dual matrix composite (C/C-SiC) disk brake [11]. The iron-based pads worked on the abrasion-based wear mechanism making it suitable for braking applications.

Advancements are also being made to incorporate nanomaterials in brake pads. Ali et al. investigated how the properties of copper friction materials can be influenced using nanosilica particles [12]. Different wt\% of nanosilica $\mathrm{SiO}_{2}$ particles were used as an additive to study the effects on the friction material's roughness and hardness. Results show that the addition of nanosilica leads to improved hardness and roughness levels of the friction material by $18.1 \%$ and $5.4 \%$, respectively. Dědková et al. introduced a nanocomposite material known as kaolin- $\mathrm{TiO}_{2}$ (KATI), and it has been used to develop an industrially available brake pad [13]. The newly formulated brake pads displayed reduced wear rates by about $50 \%$, hence leading to the greater durability of the pads. Lakshmanan studies the wear characteristics of $\mathrm{Al} /\left(\mathrm{B}_{4} \mathrm{C}+\mathrm{SiC}\right)$ hybrid nanocomposites [14]. Three parts nano-SiC and one part nano- $\mathrm{B}_{4} \mathrm{C}$ were combined with $\mathrm{Al}$ alloy to formulate the hybrid nanocomposite. The results showed an $88.3 \%$ improvement to wear resistance when compared with an unreinforced sample, making it a potential candidate to be used for brake pad applications.

Carbon nanoparticles were also utilized during the progress made in studying friction material for brake pads. As NAO pads wear quickly, they generate excessive wear particles, which can be harmful [15]. The main reason for using carbon nanomaterials as a friction modifier is their high surface area, which enables small quantities of material, enhancing the frictional characteristics [16]. Carbon nanocomposites possess high stiffness, good tribological properties, and minimum wear. Multiwalled carbon nanotubes (MWCNTs) are used as friction modifiers to control and improve the frictional properties of the composites [17]. Singh et al. discuss various properties and different processing techniques for the fabrication of carbon nanotubes [18]. Effects on mechanical and tribological properties were also reviewed. Results show that the increase in the volume fraction of CNTs in a composite leads to improved strength and resistance to wear, while also decreasing the thermal conductivity and density of the composite. This indicates that CNTs can improve the tribological properties of the pad but with a caveat of decreased thermal conductivity. Vishal et al. developed the bamboo-MWCNT-PEEK (polyether ether ketone) composite with blended synthetic particles that can be a potential friction material [19]. This composite is formulated using a hot press sintering process. The composite showed improved hardness (25\%) and thermal stability by $25^{\circ} \mathrm{C}$ and also shows properties suitable for braking applications. Hekner et al. studied the Al-SiC-C composite's various properties and tribological characteristics during the addition of 2 different carbon compounds [20]. The CNT's enhanced form of the Al-SiC-C composite leads to better matrix formulation and consistent distribution of CNTs, thereby increasing the stability of the composite. Gbadeyan and Kanny developed a hybrid nanocomposite brake pad to study its tribological and braking performance [21]. They discuss the properties possessed by the polymer-based nanocomposite which makes it a good candidate for a brake pad. MWCNT was utilized as a friction modifier in the nanocomposite to regulate the pad's frictional performance. This hybrid nanocomposite showed a reduced stopping distance by about $90 \%$ than a conventional one and also showed lower wear rates.

As put forth above, due to their favorable properties, the widespread utilization of carbon nanomaterials in various fields is being emphasized but, upon research, it is found that there exists a major downside to this. These nanomaterials pose a lot of health risks and environmental threats due to their high levels of toxicity and high penetration capability as discussed in Section 2.4. As a result of this, it is being debated by scientists, scholars, and industrialists alike on the potential of carbon nanomaterials as major alternatives to many industrial materials used currently. 
From the review conducted, it is observed that very few works of literature have analyzed the application of carbon nanotubes in the brake pads, much less the main braking performance criteria, such as the stopping distance and the stopping time, for brake pads with carbon nanocomposites. In the present study, through a thorough literature review of various studies and research works, we have investigated different nanomaterials and carbon nanomaterials and their effect on various properties. With the knowledge gained from the review, we have compared and listed the improvements that each material has exhibited. In this work, Section 2 mainly emphasizes understanding the literature. Section 2.1 discusses the technical aspect of the brake pad. Sections 2.2 and 2.3 are aimed at providing comprehensive knowledge about the current scenario of different nanomaterials and carbon nanomaterials that are being tested as a substitute for conventional asbestos material, respectively. Section 2.4 makes an effort to elucidate the potential harm that the carbon nanomaterial poses. Section 3 presents the results that are obtained from different works of literature, and it is further divided into two subsections. Section 3.1 points out the major nanomaterials and the various effects of incorporating them. Similarly, Section 3.2 helps to cast light on the effect of various carbon nanomaterials. Section 4 provides the conclusions which are drawn after meticulous study from findings of each literature. Through this review, we aim to study the possibilities of advancement in the use of nanomaterials in brake pads. The structure of the review is as shown in Figure 1.

\section{Understanding the Literature}

This section deals with the brake pad and focuses on novel and eco-friendly nanomaterials for commercial utilization in the future. In Section 2.1, a discussion on the constituents and work performance is carried out in detail. The nanomaterials could potentially replace currently used materials and elucidate the segregation of constituents into various categories and their specific roles in the brake pad. This section also discusses the primary criteria to be satisfied by the materials to be eligible for commercial usage. Section 2.2 discusses the nanomaterials that consist of naturally obtained materials such as palm kernel, banana peel, and crab shell, whereas Section 2.3 discusses carbon-based nanomaterials, which are potential competitors to current brake pad materials.

2.1. Brake Pad. Brake pads are an integral part of all disk brake assemblies, which convert the vehicle's kinetic energy into thermal energy by the action of friction, thereby stopping the rotor. In order to gain a better understanding of the work performance of a typical commercial brake pad, the design and the constituents are shown with the help of an exploded view in Figure 2.

The development of brake pads emerged from the idea of disk brakes being an alternative to the drum brakes that were earlier being used most commonly in most automotive applications. In the 24 hours of Le Mans of 1953, the incorporation of brake pads by Jaguar resulted in a much better performance than the other competitors. When this was investigated, it was found that in comparison to the drum brakes, the disk brakes provided much higher resistance to brake fade, paving the way for their widespread use in the automotive industry. Currently, there are different types of brake pads used for disk brakes, ranging from extremely soft, less durable, and aggressive types to extremely hard, highly durable, and nonaggressive types, wherein the former is mostly used in motorsport and the latter in low-power vehicles. In addition to this, in accordance with the Department of Transportation (DOT) of the USA, the brake pads are assigned a code containing two alphabets denoting the range of the coefficients of friction within which they lie; that is, for understanding the basis of classification of commercial brake pads, see Table 1 . The first alphabet denotes the coefficient of friction at cold conditions which is measured at $250 \mathrm{~F}$, and the second denotes the coefficient of friction at hot conditions, which is measured at $600 \mathrm{~F}$.

When the brakes are applied, either mechanically, hydraulically, or electronically, the brake pads are forced to come in contact with the rotating disk. The ensuing frictional contact and consequentially the heat released result in the wear of brake pad materials. As a result, it has been one of the major areas of focus of scientists and industrialists alike, and extensive research is being carried out towards the development of novel and more efficient brake pad materials, in order to minimize wear and maximize operating life.

Brake pads are mainly composites that contain constituents such as reinforcements, abrasives, fillers, and solid lubricants [1]. These composite polymeric materials are expected to exhibit good mechanical strength, lightweight features, ease of processing, thermal properties, chemical resistance, wear, and abrasion resistance applicable for tribological purposes, which have been better elucidated for comprehensibility in Figure 3. Metal matrix composites (MMCs) are generally encouraged for tribological applications due to their excellent mechanical properties and high wear resistance. Due to their high strength-to-weight ratio, light metal matrix composites are much more encouraging [2]. The shape and size of the microstructure and distribution of particles of the polymer act as an essential factor in the reinforcing effect. The pads usually consist of asbestos, semimetallic, nonasbestos organic (NAO), and low-steel, low-carbon materials.

Reinforcing fibers, friction modifiers, binders, lubricants, abrasives, and fillers are the major constituents that make up commercial automotive brake pads [3]. The fibers are the primary mechanical strength providers and stabilize brake pads and act as an essential part in the reduction of the barriers caused due to wrong utilization of ingredients [24]. These composite reinforcing fibers consist of two parts: fibers that act as the main mechanical structure and protection which has lesser mechanical strength, reinforcing and supporting the structure, and is usually called the matrix. Composite materials consist of fibers made up of many filaments whose diameters range from 5 to $15 \mathrm{~mm}$ [25]. Fibers are further classified into natural and synthetic fibers based on their availability and unavailability as readymade raw materials from nature. Natural fibers are incredibly 


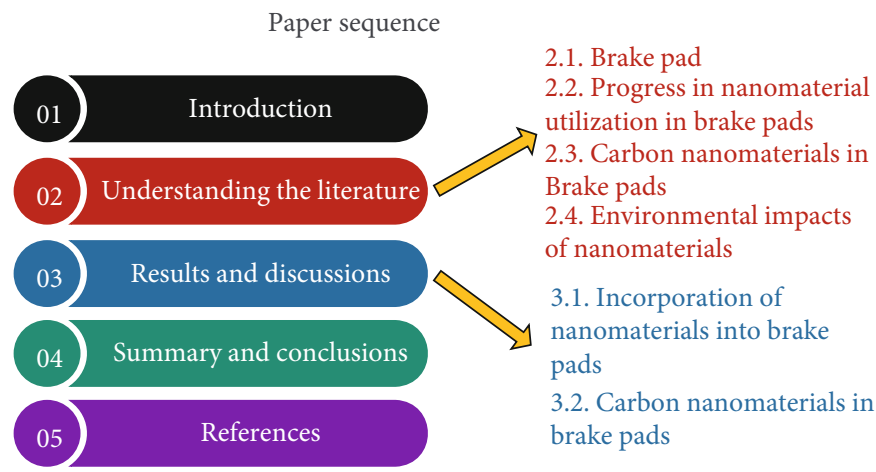

FIgURE 1: Organizational chart for the paper.

Automotive brake pad exploded view

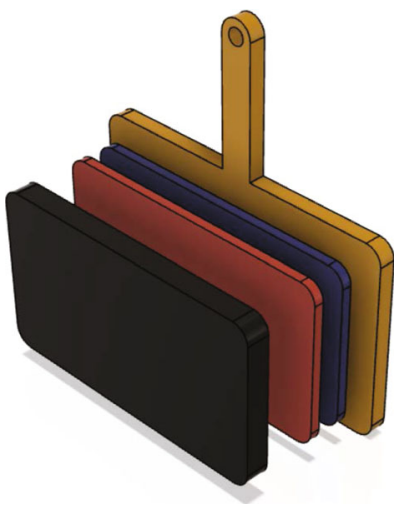

$\square$ Back plate $\square$ Under layer

Glue layer Friction material

Figure 2: Different layers of the brake pad.

TABLe 1: DOT friction codes for brake pads [22].

\begin{tabular}{lc}
\hline Alphabet & Coefficient of friction \\
\hline C & $<0.15$ \\
D & $0.15-0.25$ \\
E & $0.25-0.35$ \\
F & $0.35-0.45$ \\
G & $0.45-0.55$ \\
H & $>0.55$ \\
\hline
\end{tabular}

advantageous for cost and environmental impacts as they are recyclable and biodegradable.

Along with these advantages, the existence of multiple disadvantages of synthetic fibers like asbestos, which poses carcinogenic threats, encourages natural fibers to develop as a suitable replacement for synthetic fibers [26]. In terms of specific strength and modulus, natural fibers compare well with synthetic fibers and, with development in technology, will contend with synthetic fibers for brake pad applications [4]. Binders hold brake pad ingredients, improve bonding strength, and must possess high thermal stability, and rubber crumbs are added to improve damping properties. Abrasives help in the control of frictional properties and stabilize the brake pads under braking conditions. Solid lubricants help ensure proper sliding conditions and stabilize and provide a constant coefficient of friction within the desired range even at elevated temperatures, high loads, and highvelocity conditions at the contact surfaces. In general, solid lubricants are used at concentrations below $10 \mathrm{vol} \%$ [27]. Fillers help in cost reduction and play a significant role in improving the manufacturing ability of the commercial brake pads. Commercial brake pads usually contain high amounts of fillers, often more than $85 \mathrm{wt} \%$ [28]. The commonly used materials for these brake pad constituents have been included in Table 2 for giving a better idea when comparing the nanomaterials discussed in the further sections.

The main aim of brake pad design engineers and developers is to extract maximum performance from the brake pads within a limited surface area while also maintaining mechanical integrity [24, 29]. Therefore, the composite brake friction materials need to satisfy several significant criteria, such as providing constant friction, high wear resistance, less noise, and damping at a wide range of temperatures, pressures, and velocities [6]. In general, the wearing strain of the pad is calculated using the Archard formula given by [30]:

$$
S=C * D * L,
$$

where " $S$ " represents the strain wear, " $D$ " denotes the sliding distance, " $L$ " denotes the applied load, and " $C$ " represents the coefficient of wear.

In harsh braking conditions, the binder, usually a thermosetting phenolic resin, loses its binding ability due to the high frictional heat generated [31]. The periodic dissipation and accumulation of the heat cause cumulative adhesion of wear particles, possibly inhibiting further wear [32]. It renders unpredictable damage to the surface resulting in the improvement or deterioration of the braking efficiency. The resultant debris formed due to the wear is known as the third body, mostly made up of iron oxide from the disk brake and some other constituents of the pad. To obtain the optimal braking efficiency and functionality, the transformation of relatively more extensive brake pad constituents into the nanocrystalline third body is of utmost importance [7]. 

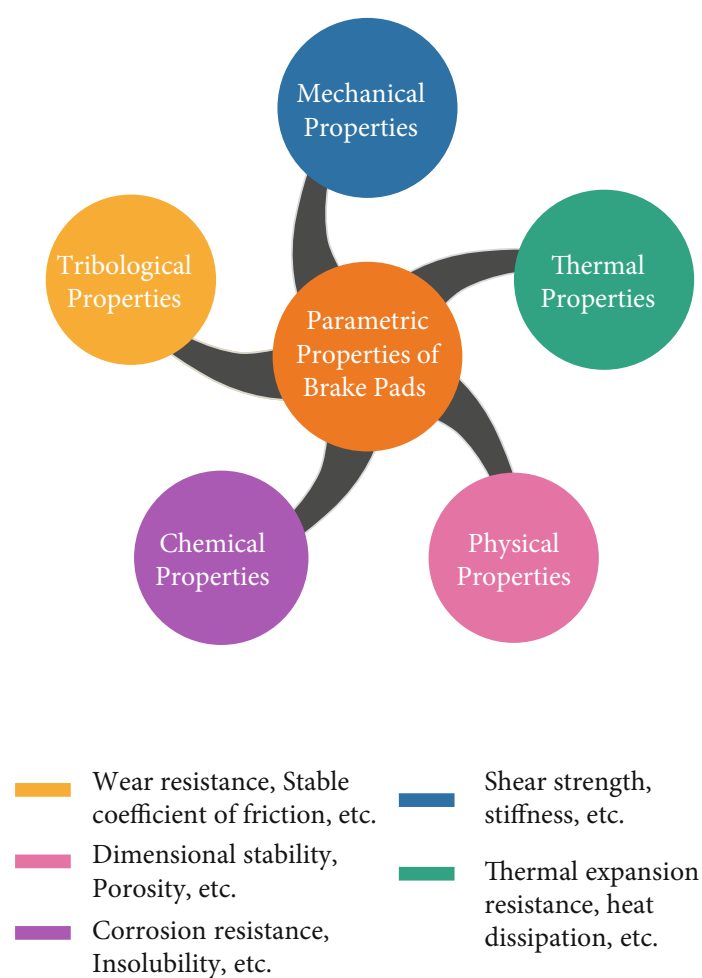

FIGURE 3: Parametric properties that a brake pad should possess [23].

Two functions are performed by the third body in general, which are to improve the surface area of contact by the formation of secondary contacts and to protect the surface areas of contact with a fragile nanostructured film. The main complexity of manufacturing brake pads lies in the fact that the composition of materials has to be optimized to result in the continuous presence of a definite and adequate amount of third body material composed of the required nanostructure at the brake pad-disk brake interface. In addition to the formation of such structures, many airborne particles are generated during the braking process when the pads scrub against the rotors and release them into the atmosphere, which is almost indistinguishable from other particles in the atmosphere $[33,34]$. These particles could be potentially toxic and hazardous to human health, and therefore, careful selection of brake pad materials has to be made to ensure a minimal number of particles are released, which are nontoxic and nonhazardous.

\subsection{Progress in Nanomaterial Utilization in Brake Pads. As} discussed in Section 2.1, the friction material of the braking system of an automobile is considered to be one of the most critical factors affecting the overall performance of an automobile. Before the restriction on asbestos was enforced in 1989 , it was the most popular and favored commercial filler material for brake pads because of its high thermal stability, tendency to regenerate the surface of friction at the time of use, high thermal resistance, high sturdiness, high flexibility, ease of availability, and comparatively lower price. As a result, with the unavailability of an alternative for a commer- cial filler material with similar properties to that of asbestos, even today, researchers are conducting extensive research in order to obtain the optimum material. Consequently, researchers began shifting their focus towards nanomaterials for studies to check the feasibility of their usage in commercial brake pad applications. Since nanomaterials, by definition, have extremely small external dimensions, lying within the range of $1 \mathrm{~nm}$ to $100 \mathrm{~nm}$, often referred to as the nanoscale, novel techniques were developed for the study of these structures. They also have improved physical and chemical properties as compared to conventional materials [35]. Nanomaterials are classified into nanoparticles, nanofibers, and nanosheets according to the number of external dimensions that lie in the nanoscale. Nanoparticles are nanomaterials that have one of their three external dimensions in the nanoscale. Similarly, nanofibers and nanosheets have two and three of their external dimensions in the nanoscale, respectively [36]. Nanofibers can be further classified as nanotubes that contain hollow structures and nanorods that contain solid structures. In addition to this, nanosheets are sometimes referred to as nanoribbons if the two larger external dimensions have a large difference in their lengths.

Barites, mica, Allium sativum, and cashew dust are a few of the most popular alternatives being studied for use as filler material $[5,37]$. The objective of the studies conducted has been to prepare a copper-based material of friction for application on a brake pad by the PM method. Moreover, in order to examine the effects of the addition of various nanosilica $\mathrm{SiO}_{2}$ particles as varying weight percentage concentrations on the resulting characteristics of the obtained friction material, a comparison of surface roughness and microhardness is made for 4 different concentrations of $\mathrm{SiO}_{2}$. A surface finish measuring instrument was used to measure the roughness of the samples, and the hardness test was done using a Vickers microhardness meter [12]. In another study, banana peel and bagasse particles with other nanoconstituents were used for the study of their frictional and wear properties for utilization as alternative commercial friction materials. The density was determined using the Archimedes method, whereas optical microscopes and scanning electron microscopes were utilized to examine the microstructure and phase distribution in samples. Additionally, the pin-ondisk method was also utilized to validate the obtained wear and friction properties [38]. In another work on similar lines, the phenolic resin (PF)/organized expanded vermiculite (OEVMT) nanocomposite was successfully prepared by mixing phenolic resin with modified expanded vermiculite. $\mathrm{X}$-ray diffraction and transmission electron microscopy followed by thermogravimetric analysis were carried out to study the structure and various properties of the nanocomposite. Finally, the properties and feasibility of the PF/ OEVMT-based brake pad were compared with those of the PF-based brake pad in order to obtain the ideal alternative nanomaterial for use in commercial brake pad applications [39]. There are multiple steps involved in the study of the effects of nanomaterials on the characteristics and properties of a brake pad, all of which are depicted in Figure 4 in order to give a general overview of the process involved, which could prove to be useful for future studies. 
TABLE 2: NAO brake pad constituents and standard materials.

\begin{tabular}{lrr}
\hline Constituents & Materials & Ref. no. \\
\hline $\begin{array}{l}\text { Reinforcing fibers } \\
\text { Binders }\end{array}$ & Brass, copper, steel, aramid, carbon, glass, jute, flax, hemp, kenaf, sisal, etc. & [23-27] \\
Abrasives & Phenolic/phenol-formaldehyde resins such as novolacs and resoles & [23-27] \\
$\begin{array}{l}\text { Solid lubricants } \\
\text { Fillers }\end{array}$ & Graphite, metal sulfides such as molybdenum, ferrous, copper, tungsten, strontium, antimony, etc. & [23-27] \\
\hline
\end{tabular}

Steps to study the effect of nanomaterials on brake pad

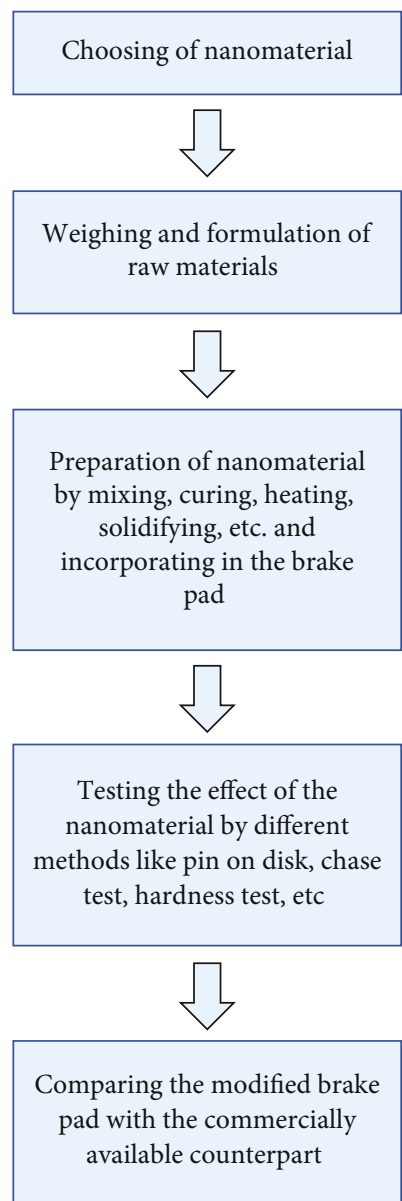

FIGURE 4: Steps to study the effect of nanomaterials on brake pads.

Determination of the optimum composition of nanocomposites containing $1 \%$ organized expanded vermiculite $(\mathrm{OEVMT})+2 \% \mathrm{SiO}_{2}, 2 \% \mathrm{TiO}_{2}$, and $2 \% \mathrm{ZnO}$ was another study's objective. The rheological characteristic was examined by using the MSCR, LAS, DSRFn value, and SSR test, and the CMAI value obtained was used to determine the aging. Four samples were prepared and were critically analyzed for their efficiency and feasibility for use in commercial applications. Fourier additionally determined resistance to aging to transform infrared spectroscopy [40]. A nanocomposite material, kaolin- $\mathrm{TiO}_{2}$ (KATI), is developed in another research work in order to improve the commercially available brake pads further. The $\mathrm{TiO}_{2}$ matrix is held in place by kaolin, consisting of 60 weight $\%$ of $\mathrm{TiO}_{2}$ nanoparticulates having a size of $18 \mathrm{~nm}$, and this composite acts as a functional filler in the commercial brake pad. The AK Master Test with a full-scale dynamometer helped describe the friction behavior under the influence of pressure, temperature, and speed. The MTK wear test helps study the pad's wear behavior [13]. In this study, a comparison is made between the mechanical properties of commercially available brake pads and boron-mixed brake pads. Five samples, each with a different weight percent of boron, were considered. A Chase machine was utilized to investigate the frictional characteristics in two cases. A Taylor Hobson Profilometer was utilized to estimate the amount of wear of the disk. Optical microscopy and SEM were utilized to examine the worn surface, and the X-ray spectrum was utilized to examine the wear debris [41]. Hybrid aluminum matrix composites reinforced with hexagonal boron nitride and graphene nanoparticles were prepared. X-ray diffraction and SEM were used to investigate the microstructures of the nanocomposites. The aim was to study the influence of the varying composition of BN and GNP-BN on the various mechanical characteristics of the matrix [42]. In addition to these, the wear resistance of brake pads utilizing powders of either boron, carbide, or boron carbide was also studied to analyze their performance concerning commercial brake pad materials [43].

Friction and wear properties under dry sliding conditions were examined for aluminum-graphite-silicon nitride (Al-Gr-Si $\mathrm{N}_{4}$ ), aluminum-silicon nitride $\left(\mathrm{Al}-\mathrm{Si}_{3} \mathrm{~N}_{4}\right)$, and aluminum-graphite (Al-Gr) composites. A Chroma Micro Vickers hardness tester was also utilized. The pin-on-disk method was utilized to evaluate the sliding wear of the samples [44]. SEM was used to analyze the wear behavior and the worn surface. $3 \mathrm{D}$ plots determined the influence of the sliding distance and load concerning wear rates. An analysis of variance test was conducted to examine the most productive process parameters influencing $\mathrm{Al}-\mathrm{Gr}$ composite wear [45]. In this study, Aluminum 6061 reinforced with three different weight percentages of $\mathrm{SiC}$ and $0.5 \%$ of $\mathrm{B}_{4} \mathrm{C}$ was studied. An ultrasonic casting process was used to prepare the hybrid composites. The pin-on-disk method was utilized to examine the abrasive wear of the test samples. Additionally, $\mathrm{Al} / \mathrm{Al}_{2} \mathrm{O}_{3}$ submicron composite materials were tested for their tribological characteristics for a brake rotor containing material made of semimetallic substances, along with determining their Vickers hardness and density values [46].

SEM and TEM were used to investigate the microstructure of the samples [14]. Crab shell powder was used in the development of brake pads. Thermal stability, high 
hardness, density, and loss on ignition characteristics were depicted by thermally processed CBS powder and its friction composite. CBS powder-based friction composites depicted higher performance, as well as standard and fade friction coefficients. The CBS powder-based $\mathrm{NAO}_{2}$ composite is better based on the performance friction coefficient and thermal stability, whereas the NAO1 composite is better in the fade, recovery rate, and wear loss [47]. Micro-nanocomposites can also be utilized to formulate the harsh environment-resistant triboelectric nanogenerator (TENG) that can work as a safety warning system in brake pads by automatically giving timely warnings and reminders for brake pad replacements [48]. This mechanism uses the micro-nanocomposite to make the system wear-resistant and act as a triboelectric conduction medium.

2.3. Carbon Nanomaterials in Brake Pads. The fall of asbestos as a friction material led to the rise of metallic, semimetallic, sintered, and NAO materials for their use in brake pad applications. However, studies revealed that brake pads with high metal or semimetallic content caused faster disk degradation while producing excessive noise [49]. Also, although NAO pads are softer and produce less noise, they wear quickly and generate excessive wear particles that are extremely harmful to the lungs [25]. Therefore, researchers started to look towards nanoparticles as a potential source to improve the brake pads' tribological and wear performance with this caveat. As a result, many nanocomposites were developed and tested over the years and were observed to contain many of the required properties needed for the brake pads, as discussed in Section 2.2. These pads are often regarded as superior to commercially available brake pads in performance and longevity [50]. But still, researchers continue to look for other materials to improve the brake pad's tribological properties.

Carbon nanomaterials have a large surface area, and the addition of small quantities of these materials can significantly impact the frictional properties of the composites. This is one of the main reasons for using carbon nanomaterials as a friction modifier in composites [16]. Composites formed through the addition of carbon nanomaterials are known as carbon nanocomposites (CNCs). These composites have high stiffness, good tribological properties, and minimum wear, as they are optimal for brake pad applications. Table 3 depicts some of the $\mathrm{CNC}$ brake pads developed in the literature. We can conclude that carbon nanotubes (CNTs) are the most commonly used carbon nanomaterial to formulate these brake pads, and some of the most common and developing methods of their preparation for commercial usage have been depicted in Table 4, and Figure 5 depicts the setup for the electric arc synthesis process. These have been included keeping in mind that this may be useful for future studies and research works regarding the preparation of carbon nanomaterials for various applications.

Mainly multiwalled carbon nanotubes (MWCNTs) are used as friction modifiers to control and improve the frictional properties of the composites. MWCNTs have high stiffness, heat resistance, good damping factors, and low density $[17,57]$, making them helpful in improving the composite's thermal conductivity and mechanical and tribological properties [21]. CNCs are prepared by mixing the resin, binders, friction modifiers, lubricants, and abrasives in specific ratios and have been elucidated in Table 3 for providing an elaborate overview into the prospect of many CNCs for brake pad applications, which could be used as a base for focusing upon in the future. Single-walled carbon nanotubes (SWCNTs) also have the potential to be incorporated into brake pad composites. While more testing is required to analyze the frictional characteristics of the material, they show significant wear resistance and can act as lubrication to the tribological system [58].

The carbon nanosphere can also be used to formulate $\mathrm{CNC}$ and hybrid nanopolymer composites as it helps to improve the thermal stability of the friction material [54]. One other innovative CNC, a potential friction material, is the bamboo-MWCNT-PEEK composite [19]. PEEK (polyether ether ketone) is a high-performance thermoplastic with outstanding mechanical and thermal properties making it optimal for tribological applications. The addition of MWCNT and synthetic diamonds in small quantities as a double reinforcement improves wear resistance and mechanical and thermal properties of PEEK [19].

2.4. Environmental Impacts of Nanomaterials. The rapid development and use of nanomaterials in all industries make them widespread and a potential solution to many of the current technical difficulties faced by the industries. However, consistent use of these materials leads to significant accumulation and can harm humans and the environment. Nanomaterials are known for their large surface area to volume ratio, leading to many molecules in the same area. With the increase in the number of molecules, there is a significant increase in the accumulated intrinsic toxicity of the material. The toxicity of the material depends not only on size and shape but also on its other physical and chemical properties. And due to their small dimensions, they get absorbed quickly in many biological systems leading to their accumulation, especially the materials with low solubility, which can stay in the system for a longer duration [60, 61].

Engineered nanoparticles play a major role in the degradation of the environment. When these particles interact and bind with the naturally present nanoparticles or soil particles, these particles aggregate, which is not easily degraded. Figure 6 depicts the process of how the engineered particles disperse, react, and accumulate to affect the environment, in order to provide awareness on the potential effects of the widespread utilization of carbon nanomaterials. Studies have shown that this leads to a decrease in the fertility of the soil [62]. For example, carbon 70 fullerenes and multiwalled nanotubes (MWNTs) reduce rice yield, while CNTs exposed to wheat make them vulnerable to pollutants present in the ecosystem [60]. Engineered nanoparticles can be released into the atmosphere during the production of nanomaterials, manufacturing of products utilizing nanomaterials, and use of products containing nanomaterials [63]. Formulation of nanomaterials is also an energy- 
TABLE 3: Various carbon nanomaterials used for brake pad applications.

\begin{tabular}{|c|c|c|c|c|c|}
\hline Research purpose & $\begin{array}{c}\text { Carbon } \\
\text { nanomaterial } \\
\text { used }\end{array}$ & $\begin{array}{l}\text { Composition } \\
\text { of brake pad } \\
\text { friction } \\
\text { materials }\end{array}$ & $\begin{array}{l}\text { Testing } \\
\text { methodology }\end{array}$ & Material characterization & $\begin{array}{l}\text { Ref. } \\
\text { no. }\end{array}$ \\
\hline $\begin{array}{l}\text { To analyze the tribological } \\
\text { performance of CNT containing brake } \\
\text { friction material }\end{array}$ & CNT & $\begin{array}{l}\text { Vol (\%): } \\
\text { (i) Resin (15\%) } \\
\text { (ii) Kevlar } \\
\text { (10\%) } \\
\text { (iii) Barite } \\
\text { (0\%) } \\
\text { (iv) Zircon } \\
\text { (5\%) } \\
\text { (v) Graphite } \\
\text { (10\%) } \\
\text { (vi) CNT } \\
\text { (60\%) }\end{array}$ & $\begin{array}{l}\text { (i) Krauss-type } \\
\text { tester } \\
\text { (ii) } 1 / 5 \text {-scale brake } \\
\text { dynamometer }\end{array}$ & $\begin{array}{l}\text { (i) Thermal conductivity }(\mathrm{W} / \mathrm{m} \mathrm{K}) \\
0.653 \\
\text { (ii) Specific wear rate } 1.7 * 10^{-3} \mathrm{~m} \\
\mathrm{~m}^{3} / \mathrm{Nm} @ 100^{\circ} \mathrm{C} \\
\text { (iii) } \mathrm{COF} \approx 0.51\end{array}$ & {$[16]$} \\
\hline $\begin{array}{l}\text { To study the damping behavior of } \\
\text { carbon and glass under the effects of } \\
\text { surface treatments }\end{array}$ & MWCNT & $\begin{array}{l}\text { Wt (\%): } \\
\text { (i) Carbon } \\
\text { fiber (4\%) } \\
\text { (MWCNT-F } \\
\text { grafted) } \\
\text { (ii) Glass fiber } \\
\text { (HNO } \\
\text { treated) (34\%) } \\
\text { (iii) Phenolic } \\
\text { resin (50\%) } \\
\text { (iv) Zirconium } \\
\text { silicate (5\%) } \\
\text { (v) Graphite } \\
\text { (2\%) } \\
\text { (vi) Barium } \\
\text { sulfate (2\%) } \\
\text { (vii) Rubber } \\
\text { powder (3\%) }\end{array}$ & $\begin{array}{l}\text { (i) FFT analyzer } \\
\text { (ii) FTIR analysis } \\
\text { (iii) } \\
\text { Thermogravimetric } \\
\text { analysis }\end{array}$ & $\begin{array}{l}\text { (i) Sample } \mathrm{S} 3\left(\mathrm{HNO}_{3} \text {-treated GF }\right. \\
34 \mathrm{wt} \% \text { and } \mathrm{MWCNT}-\mathrm{F} \text { grafted on } \\
\mathrm{CF} 4 \mathrm{wt} \%) \\
\text { (ii) Weight loss } 0.202 \mathrm{mg} \\
\text { (iii) Damping ratio } 0.064\end{array}$ & [51] \\
\hline
\end{tabular}

(i) $100 \mathrm{~m}$ at $25^{\circ} \mathrm{C}(\mathrm{RT}) \& 250 \mathrm{~m}$ at $450^{\circ} \mathrm{C}(\mathrm{HT})$

With CNT:

(i) Avg. cross-section of the wear $\operatorname{track}\left(\mathrm{mm}^{2}\right)$ :

Wt (\%):

(i) $\mathrm{CNT}(1 \%)$

Tribological behaviors of the $\mathrm{Al}-\mathrm{SiC}(n)$ hybrid composite with carbon addition
MWCNT

(ii) Aluminum

(83.4\%)

(iii) Silicon carbide (15.6)
$\mathrm{RT}=0.027 \pm 0.001, \mathrm{HT}=0.372 \pm$ 0.001

(i) Dry sliding wear (ii) Wear rate $\left(\mathrm{mm}^{3} / \mathrm{Nm}\right)$ :

tests $\quad \mathrm{RT}=0.002$

(ii) SEM and EDS

$\mathrm{HT}=0.009$

(iii) COF:

$\mathrm{RT}=0.63 \pm 0.052$

$\mathrm{HT}=0.79 \pm 0.12$

(iv) Surface roughness $(\mu \mathrm{m})$ :

$\mathrm{RT}=1.4$

$\mathrm{HT}=13.5$

(v) Hardness $(\mathrm{GPa})=1.61$
Influence of short carbon fiber on carbon nanotubes as a friction material for brake pads
Wt (\%):

MWCNT (i) Pin-on-disk wear Epoxy+CF (10 wt \%)+0.1wt. CNTs
(i) Epoxy resin test (ASTM G-99)
(i) Wear rate $=3.45 \mathrm{~mm}^{3} / \mathrm{Nm} \cdot 10^{-6}$

$(89.9 \%)$

(ii) SEM

(ii) COF 0.32 
TABLE 3: Continued.

\begin{tabular}{|c|c|c|c|c|c|}
\hline Journal of Nanomaterials & & & & & c \\
\hline \multicolumn{6}{|c|}{ TABle 3: Continued. } \\
\hline \multirow[t]{2}{*}{ Research purpose } & $\begin{array}{c}\text { Carbon } \\
\text { nanomaterial } \\
\text { used }\end{array}$ & $\begin{array}{l}\text { Composition } \\
\text { of brake pad } \\
\text { friction } \\
\text { materials }\end{array}$ & $\begin{array}{l}\text { Testing } \\
\text { methodology }\end{array}$ & Material characterization & $\begin{array}{l}\text { Ref. } \\
\text { no. }\end{array}$ \\
\hline & & $\begin{array}{l}\text { (ii) Short } \\
\text { carbon fiber } \\
(10 \%) \\
\text { (iii) MWCNT } \\
(0.1 \%)\end{array}$ & & $\begin{array}{l}\text { (iii) Compressive modulus }(\mathrm{GPa})= \\
1.87 \\
\text { (iv) Compressive strength }(\mathrm{MPa})= \\
1.88 \\
\text { (v) Hardness }=37.5 \mathrm{HB}\end{array}$ & \\
\hline
\end{tabular}

Wt (\%):

(i) Graphite nanoparticles $(0.3 \%)$

Study of the biobased hybrid nanocomposite as a friction material for brake pads

Carbon nanospheres (CNS) (ii) Epoxy resin $(98.7 \%)$

(iii) CNS

(0.2\%)

(iv) Stainless

steel

nanoparticles

$(0.8 \%)$

\begin{tabular}{|c|c|c|c|c|c|}
\hline $\begin{array}{l}\text { Development and analysis on low- } \\
\text { friction hybrid nanocomposite friction } \\
\text { materials for brake pads }\end{array}$ & MWCNT & $\begin{array}{l}\text { Vol (\%): } \\
\text { (i) Epoxy resin } \\
\text { (86.7\%) } \\
\text { (ii) Carbon } \\
\text { fiber (10\%) } \\
\text { (iii) MWCNT } \\
\text { (0.3\%) } \\
\text { (iv) Graphite } \\
\text { nanopowder } \\
\text { (3\%) }\end{array}$ & $\begin{array}{l}\text { (i) } \\
\text { Thermogravimetric } \\
\text { analysis } \\
\text { (ii) Dynamic } \\
\text { mechanical analysis } \\
\text { (iii) Differential } \\
\text { scanning } \\
\text { calorimetry } \\
\text { (iv) Inertial } \\
\text { dynamometer test }\end{array}$ & $\begin{array}{l}\text { HC6: } \\
\text { (i) Compressive strength }(\mathrm{MPa})= \\
988 \\
\text { (ii) Compressive modulus }(\mathrm{GPa})= \\
1.709 \\
\text { (iii) Mean shear strength }=1.250 \\
\mathrm{MPa} \\
\text { (iv) Impact strength }\left(\mathrm{kJ} / \mathrm{m}^{2}\right)=8.7 \\
\text { (v) Hardness }=35 \mathrm{HV} \\
\text { (vi) Water absorption }=0.01 \% \\
\text { (vii) Oil absorption rate }=0.1 \% \\
\text { At } 21.6 \mathrm{~m} / \mathrm{s}: \\
\text { (i) Wear rate }(\mathrm{g} / \mathrm{Nm})=4.47 * 10^{-8} \\
\text { (ii) COF }=0.399\end{array}$ & [55] \\
\hline
\end{tabular}

$\mathrm{Wt}(\%):$

(i) $\mathrm{PF}(15 \%)$

(ii) Barium sulfate $(50 \%)$

Impact of nanoclay and CNTs on friction performance of nanofilled hybrid fiber-reinforced phenolic composites (iii) Kevlar

MWCNT

fiber $(2.5 \%)$

(iv) Nanoclay

(1.375\%)

(v) MWCNT

(1.375\%)

(vi) Graphite

(2.25\%)

\section{(i) Dynamic}

mechanical analysis

(ii)

Thermogravimetric

analysis

(i) Compressive strength $=3557.3$ $\mathrm{MPa}$

(ii) Impact strength $\left(\mathrm{kJ} / \mathrm{m}^{2}\right)=3.3$
Wt (\%):

(i) Epoxy resin

(83.8\%)

(ii) Carbon

Tribological performance of polymer hybrid nanocomposite brake pads
MWCNT fiber (15\%) (iii) MWCNT (0.2\%)

(iv) Graphite nanopowder (1\%)
NCT-1:

(i) Water absorption $(\%)=1.74$

(ii) Shear strength (Kgf) $=925$

(iii) Compressibility (\%) $=1.16$

(iv) Impact strength $(\mathrm{J})=0.162$

(v) Hardness HRR $=107$

(vi) $\operatorname{COF}($ performance $\mu \mathrm{p})=0.39$

(vii) Wear (g) $=7.8$
HC6 @ $21.6 \mathrm{~m} / \mathrm{s}:$

(i) $\mathrm{COF}=0.40590246$

(ii) Stopping distance $=1.75 \mathrm{~s}$ dynamometer test

dynamometer test

Ref.

\begin{tabular}{|c|c|c|}
\hline 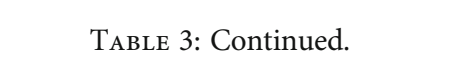 & & \\
\hline 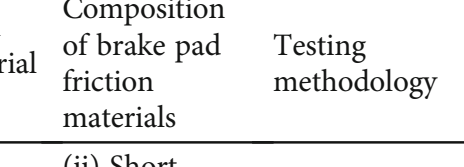 & Material characterization & $\begin{array}{l}\text { neff } \\
\text { n }\end{array}$ \\
\hline 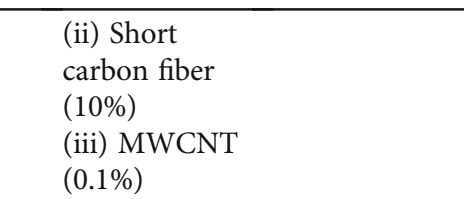 & 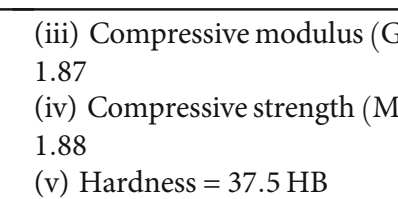 & \\
\hline
\end{tabular}


TABLE 4: Common and upcoming modes of preparation of CNTs [59].

Sl.

Process

1. Electric arc synthesis

2. Laser-assisted synthesis

3. Resistivity vaporization

4. Ion-beam vaporization

5. Sunlight vaporization

6. Pyrolysis of hydrocarbons

7. Decomposition of metal carbides

8. Synthesis in flame

9. Electrolysis of molten salt

10. Chlorination of carbides
Brief procedure

With graphite electrodes, inert gas atmosphere, and high temperature, there is transfer and deposition of carbon atoms/ions from the anode to the cathode as shown in Figure 5. As a result, amorphous carbon, SWCNT, and MWCNT are formed.

The evacuated quartz tube with a graphite rod placed axially is heated to $1200^{\circ} \mathrm{C}$ and supplied with argon. The laser is shot at the target, causing carbon atoms to get deposited on the tube walls, collected with cooled copper fingers. As a result, carbon nanoparticles and MWCNT are obtained.

Joule heating of a graphite foil, followed by cooling of vapors, results in the deposition of the nanotube on single-crystalline graphite and produces majorly SWCNT with traces of MWCNT, bundles of nanotubes, and nanocones of carbon.

Ions when bombarded with high-purity graphite in a tube at high speeds in vacuum result in the deposition of CNT on the walls of the tube, along with traces of polyhedral carbon nanoparticles.

Sunlight concentrators vaporize graphite in a tube with the aid of a catalyst, resulting in the deposition of SWCNT and MWCNT on the walls of the tube.

Heating of compounds such as acetylene, methane, benzene, and carbon monoxide at a certain pressure in the presence of a catalyst such as graphite-iron compound, nickel-magnesium oxide compound, and iron results in the formation of amorphous carbon, SWCNT, and MWCNT.

Breakdown of metal carbides by arc heating, laser ablation, or resistive vaporization results in the formation of MWCNT.

Combustion of hydrocarbons in oxygen produces CNT, much like diamonds and fullerenes, but only in the presence of a catalyst.

Electrolysis of molten chlorides of lithium, sodium, and potassium, in the presence of carbon electrodes at $600^{\circ} \mathrm{C}$, results in a sludge, which, when washed off with water and toluene, results in MWCNT being obtained, along with particles of spheroidal and polyhedral shapes.

Chlorination of carbides at silicon and tantalum at 800 to $850^{\circ} \mathrm{C}$ results in the formation of MWCNT.

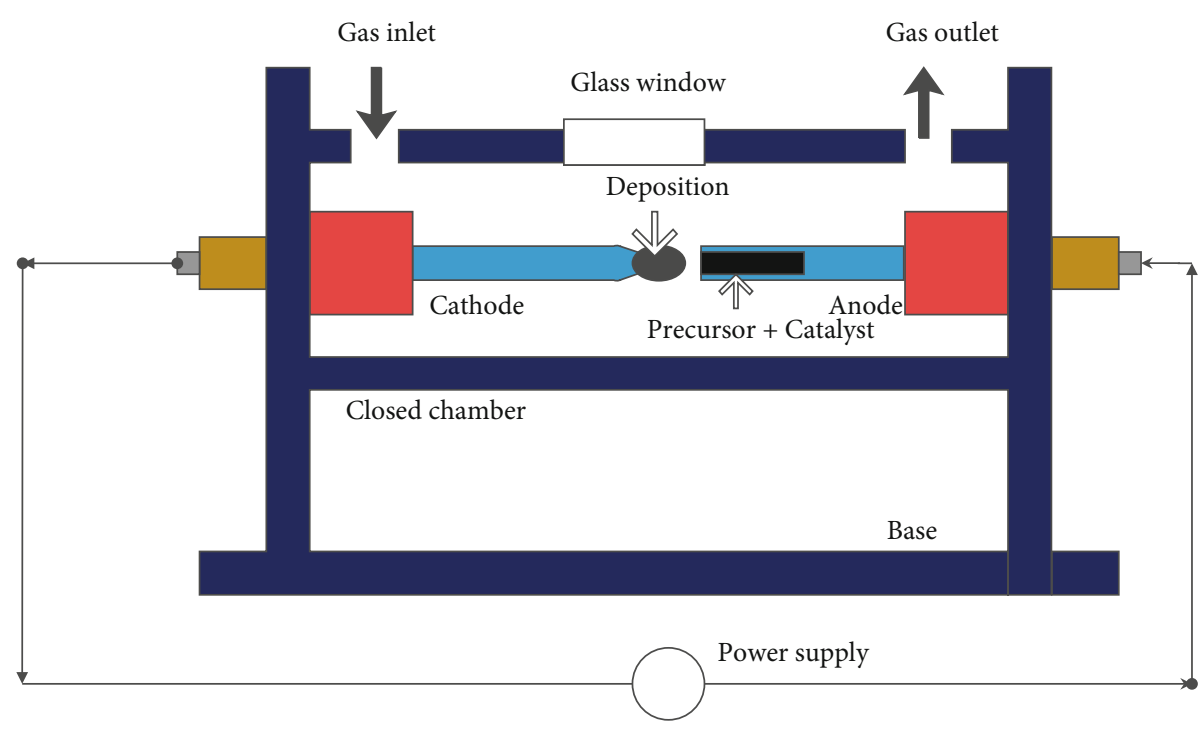

FIGURE 5: Setup for a typical electric arc heating process.

intensive process requiring a large amount of water, energy, and chemicals.

Brake pads, upon constant use, tend to wear and release debris into the atmosphere, and this debris can be harmful depending on the composition of the pads [64]. If inhaled, brake pad debris present in the atmosphere can induce chromosomal damage in natural blood situations [65], cause inflammation to lung tissues, and change cell morphology.
Brake pads emit a significant number of airborne particles; hence, the interactions between these particles and environments must be studied [66]. With the utilization of carbon nanomaterials in brake pads, it becomes imperative to check the toxicity of the wear debris released and understand the interactions of this debris with the environment.

The main constituent of the majority of carbon nanocomposites is CNT. Due to their large surface area and high 


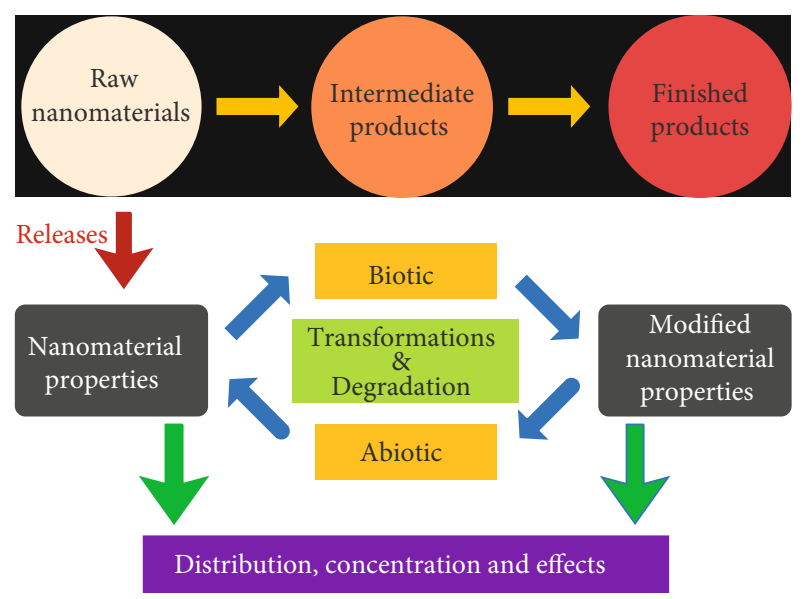

Figure 6: Process of dispersion and accumulation and effects of engineered nanoparticles.

adsorption capabilities, CNTs also bind with other pollutants in the environment. Depending on the type of pollutant and CNT's properties, the compound's toxicity can increase significantly [67]. An example would be the enhancement of toxicity of $\mathrm{Cu}$ and $\mathrm{Cd}$ under the exposure of CNTs [68]. MWCNTs act as inhibitors in the soil by preventing biomass and microbe activity, thereby reducing soil fertility [67]. MWCNTs are also found to damage root cells, inhibit nutrient absorption, and cause DNA and chromosome deviations in plants [69].

CNTs can also affect human systems [70]. They can enter our bodies through windpipes and accumulate in the lungs, causing inflammation and tumors upon extended exposure [71]. Some CNTs behave like asbestos and can play an active role in the development of lung cancer. Mainly long CNTs cause mesothelioma, a type of lung cancer previously caused by asbestos exposure [72]. The toxicity of the CNTs increases with the length of the CNTs [73]. MWCNT shows a peculiar case of toxicity that can inhibit DNA repair in cells [71]. With the increasing use of the CNT, it becomes essential that the long-term effects of its accumulation on the environment be researched to understand its effects on the environment qualitatively and humans.

Currently, there is a lack of studies on the wear debris released through carbon nanocomposite brake pads and its effect on the environment. Without proper evaluation of the types of carbon nanomaterials released through the tribological actions, it becomes difficult to quantify the extent of these materials' effects on the environment.

\section{Results and Discussions}

From Table 5, we get an idea of the amount of research carried out on the analysis of brake pad abrasion characteristics. This helps in getting to know the most common tools utilized for commercial brake pad testing with the help of the studies reviewed. The setups of the typical brake pad friction, abrasion, and hardness testing have been shown in Figures 7 and 8 in order to help comprehend the brake pad performance testing processes. Pan and Chen proposed a three- layer structure for the brake pad by analyzing a kinematic model of the brake pad with six degrees of freedom [74]. The study proved that the mass and stiffness of a brake pad played an essential role in its stability, followed by a brake bench test to validate the results. The results showed that the design of the three-layer structure and the slotted design of the brake pad could effectively reduce brake squeal, especially high-frequency squeal noise. This study helps realize that even though engineers try to minimize the mass, it is crucial to have a minimum mass limit for a brake pad to ensure its stability and ease of operation.

Wan et al. proposed a model of COF based on rigid particles and contact mechanics [81]. This model considers the influence of particle size and amount of reinforcing pillars, brake pad and disk properties, and other constituents of the pad. The results indicate that there is an increase in the COF of the brakes relative to the disk surface topography. This model also estimates the size of the friction film through the incorporation of rigid particles into the model. Through this, it can be concluded that the frictional power of brakes increases with the size of the rigid particles. Wang and $\mathrm{Fu}$ analyzed the relationship between the structure of a brake pad and the distribution of temperature and thermal stress on the disk brake. The modes of heat transfer considered for the transmission of kinetic energy from the brake pad in this study were convection and radiation. In addition to this, it involved the optimization of the brake pad structure and the arrangement of friction blocks on the brake pad, along with temperature and thermal stress distribution analysis for the optimized brake pad and subsequent validation by simulation. The study observed a more uniform temperature distribution and a lower maximum temperature on the disk surface, increasing the radial structural factor accompanied by a decrease in the circumferential structural factor. The structural program upon optimization showed that on a brake pad with five friction blocks, the maximum temperature and stress were $4.9 \%$ and $10 \%$ lower, respectively, than that of a brake pad with seven friction blocks. From this study, we can conclude that it is better to have fewer friction blocks incorporated in a brake pad with higher and lower radial and circumferential structural factors, respectively [75].

$\mathrm{Wu}$ et al. conducted a study to analyze the transient thermal and mechanical behavior of the brake pad and disk brake system [76]. It was concluded that a steady temperature distribution state could be reached with uniform vehicle speed and braking pressure after several braking stops. The study also predicted that when used for speed or pressure sensitivity application, the temperature distribution state would oscillate and is generally caused due to chemical changes in friction material. Eltayb and Hamdy proposed models that constitute a robust methodology and could be used to predict the friction coefficients and the induced interface temperature of brake pad materials to reduce experimental time and cost [77]. With further research and development of this technology, this could, in principle, drastically reduce testing time, cost, and workforce. Kumar and Ghosh studied the wear particles originating from a brake pad system that contribute to particulate 
TABLE 5: Tools used for the analysis of brake pads in different studies.

\begin{tabular}{lll}
\hline Tools used for analysis & Reference \\
\hline Linear complex eigenvalue analysis & {$[74]$} \\
ABAQUS and MATLAB & {$[75]$} & {$[76]$} \\
SAE J2522 inertial dynamometer and finite element analysis & {$[77]$} \\
Least-squares support vector machines & {$[1]$} \\
TSI P-Trak, GRIMM aerosol spectrometer, and scanning mobility particle sizer & {$[15]$} \\
Dynamometer, scanning electron microscopy, energy-dispersive X-ray spectroscopy, and Raman microspectroscopy & [78] \\
Dynamometer, flow splitter (TSI 3708), aerodynamic particle sizer (APS; TSI 3321), optical particle counter (OPC; GRIMM & [79] \\
1.109), fast mobility particle sizer (FMPS; TSI 3091), and air samplers & {$[80]$} \\
Dynamometer Global Brake Effectiveness procedure (SAE J2522)
\end{tabular}

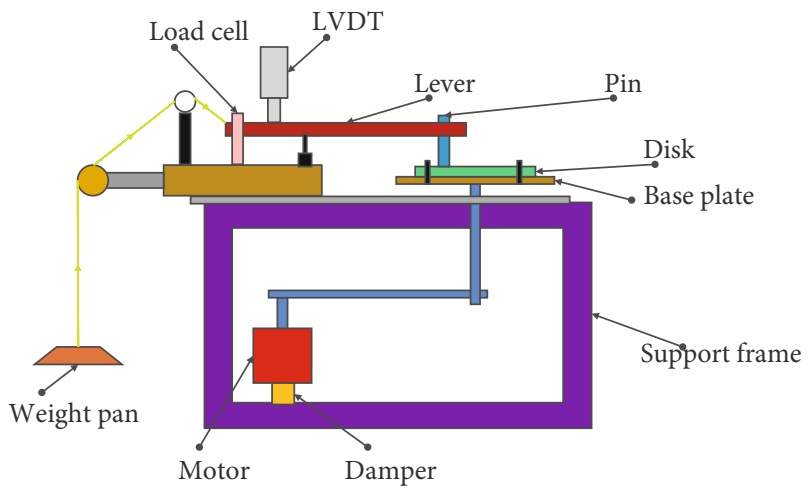

FIGURE 7: Typical setup of brake pad friction testing.

concentration in the urban atmosphere $[1,82]$. In this study, ultrafine and micron-sized particles along with aerodynamic nanoparticles were measured. The investigation under various loads and sliding velocities found that wear particles emitted from the brake pad material varied in diameter between 10 nanometers and 10 micrometers, categorized as shown in Figure 9, which helps us realize the basis of classification of brake pad wear particles that could possibly result in health hazards to the human respiratory system and harm the environment.

Barosova et al. studied the toxic effects of the brake pad wear materials generated during braking and released into the atmosphere on the human lungs [15]. A full-scale dynamometer was used in a controlled environment to generate wear particles from low-metallic and NAO brake pads, and analysis tools were applied to analyze the morphological properties of the wear particles. This study used a human 3D multicellular model consisting of epithelial and primary immune cells that simulated the human epithelial tissue barrier and exposed it for 24 hours to nonairborne particles and other wear fractions. This helped assess the viability, oxidative stress, morphology, and inflammatory response of the cells. The results indicated no response from the lung cells from wear particles of low-metallic pads, whereas particles from NAO (due to anatase) pads increased inflammatory response, reduced viability, and altered cell morphology. In addition to this, the study concluded that $\mathrm{TiO}_{2}$ produced from brake pads caused increased toxicity of the wear particles. Namgung et al. studied the changes in the particle size distribution concerning braking time under various braking conditions [78]. The study found that the size distribution of particles ranged from 5.6 to 560 nanometers, and under all braking conditions, the peak value ranged between 178 and $275 \mathrm{~nm}$ with an absolute maximum at 200 nanometers. The study indicated that the total number concentration of ultrafine particles generated varied with disk speed and brake force and thus was found to be proportional to the contact surface temperature. Upon further investigation, it showed that the number of ultrafine particles generated exponentially increased when the surface temperature reached $70^{\circ} \mathrm{C}$. Therefore, they formulated the critical temperature for the generation of 10-nanometer-ranged nanoparticles to be around $70^{\circ} \mathrm{C}$, which was also found to be the average temperature between the surface and inside the disk. At higher temperatures, they observed vapors due to evaporation and condensation, following which the vapors cooled down quickly and underwent nucleation to form nanoparticles, and when their concentration increased drastically, they formed agglomerates through coagulation.

Zhang et al. studied the characteristics of $\mathrm{Cu}-\mathrm{Fe}$ prealloyed powders that are atomizing with argon gas to utilize $\mathrm{Cu}$-based composites for brake pad applications [83]. They display very high friction coefficients and friction stability characteristics while also exhibiting reduced wear loss at low braking speeds $(<200 \mathrm{~km} / \mathrm{h})$. It exhibits an unstable friction coefficient and higher wear loss at high braking speeds $(>200 \mathrm{~km} / \mathrm{h})$. Kumar et al. analyze the properties of sintered $\mathrm{Cu}-\mathrm{Sn}$ brake pads used in harsh environments and off-road purposes [84]. These have a low wear rate, high shear strength, and good frictional properties. However, this material is very abrasive, causing deformations, cuts, and pits on the brake drums. The coefficient of friction decreases as the temperature increases, and although this decrease is slight, this property is not desirable on brake pads. They also showed a more significant variation among fade and recovery functions with increased usage. Ultimately, this composite has good strength but poor performance at higher temperatures while also causing damage to the brake drums and disks. Noda and Takei investigated the phenomenon of 


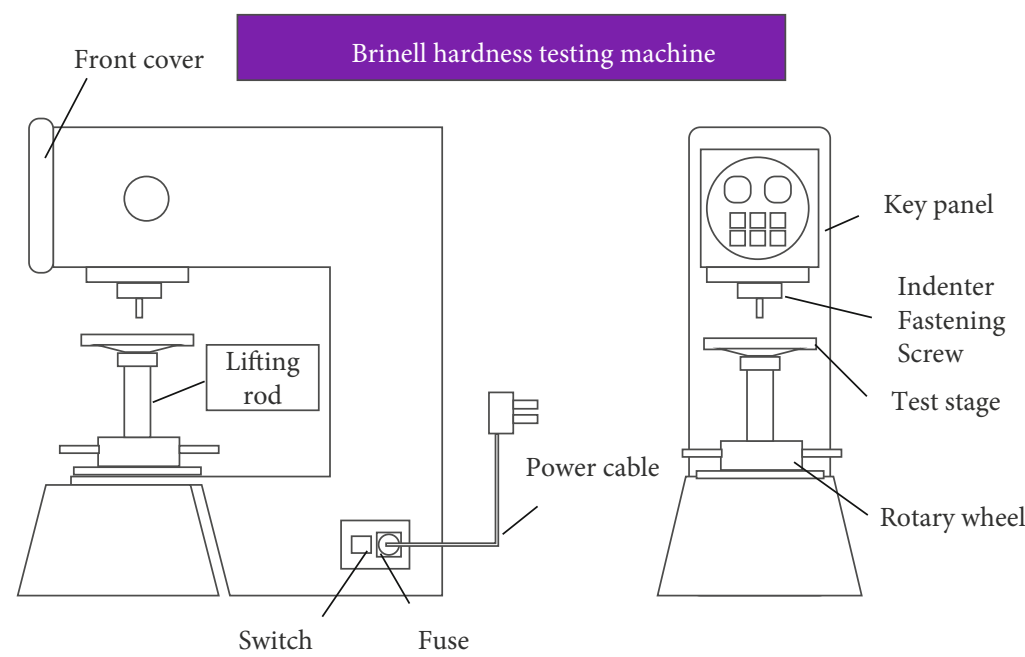

FIGURE 8: Schematic representation of a Brinell hardness testing machine.

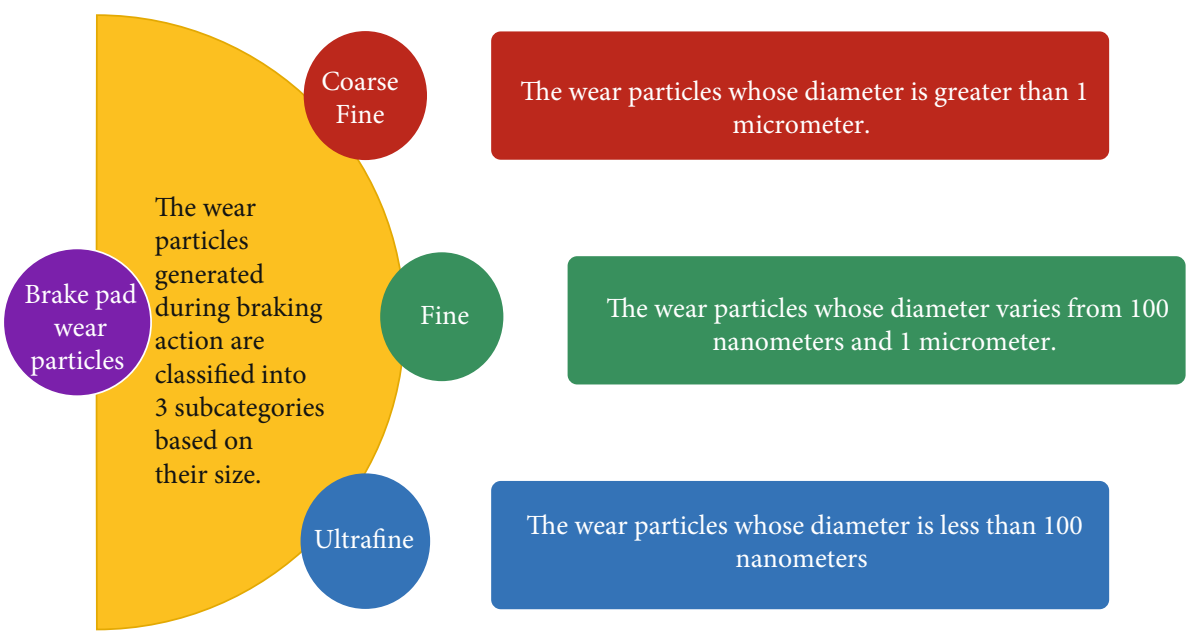

Figure 9: Wear particles classified based on size.

metal pickup in automotive disk brake pads that happens due to the accumulation of metals on the pad surface [85]. The study indicated that most of the metal pickup happens due to the reduction process of magnetite present in the brake rotors, hindering brake pad performance. Therefore, this phenomenon must be stopped to ensure the effective functioning of automobile braking systems. Sriwiboon et al. conducted a study to analyze the properties of two brake pads, one based on a low-copper NAO and another based on a copper-free NAO, both with samples of varying porosity for friction, wear, and brake squeal [86]. The study concluded that with increasing porosity, the hardness and natural frequency of the brake pad decrease continuously. Also, the study showed that as the porosity increased, the friction coefficient and the wear decreased for the lowcopper NAO samples, whereas the friction coefficient increased with an unchanged wear rate for the copper-free NAO samples.

3.1. Incorporation of Nanomaterials into Brake Pads. Table 6 depicts the improvements in various parameters when dif- ferent nanomaterials are incorporated in the brake pad, in order to provide a quantitative view which would lead to better comprehensibility.

Table 7 provides an understanding of the parameters on which different nanomaterials are assessed. This table also helps in getting to know the most commonly studied nanomaterials for future commercial brake pad applications and could help future works to focus on improving some of these parameters.

As the amount of nano- $\mathrm{SiO}_{2}$ is increased in the samples, the value of hardness increases linearly. Also, the roughness increases with an increase in the amount of $\mathrm{SiO}_{2}$ in the sample. The abrasive characteristic of $\mathrm{SiO}_{2}$ particles explains the effect of the increase of surface roughness [12]. Optical microscopy and scanning electron microscopy revealed the uniform distribution of the particles in the matrix. The relative density of the samples was much higher than their commercial counterparts as they exhibited minor porosity as measured by the oil diffusion test. The highest hardness value was exhibited by the BG5 sample (5 weight\% of bagasse). The rate of wear measured using the pin-on-disk 
TABLE 6: Some nanomaterials suitable for braking applications.

\begin{tabular}{|c|c|c|}
\hline Nanomaterial used & Improvements & Reference \\
\hline Wet granulated cornstalk fiber & $\begin{array}{l}\text { (i) The rate of wear of wet granulated samples lowered by } 26.13 \%-37.53 \% \\
\text { (FG-5: } 26.13 \% \text {; FG-7: } 35.90 \% \text {; FG-9: } 35.74 \% \text {; FG-11: } 37.53 \% \text {; FG-13: } 27.63 \% \text { ) } \\
\text { when compared with samples prepared by PM }\end{array}$ & [87] \\
\hline Fused mullite & $\begin{array}{l}\text { (i) Density reduced from } 6.2 \mathrm{~g} / \mathrm{cc} \text { to } 2.40-2.72 \mathrm{~g} / \mathrm{cc} \text { for three different } \\
\text { samples } \\
\text { (ii) The wear rate for the sample containing } 3 \mathrm{wt} \% \text { of mullite decreased from } \\
1 \mathrm{~g} \text { to } 0.887 \mathrm{~g}\end{array}$ & {$[88]$} \\
\hline Nanosized $\mathrm{SiO}_{2}$ particles & $\begin{array}{l}\text { (i) With the addition of } 9 \% \mathrm{SiO}_{2} \text {, there was an improvement of } 18.11 \% \text { in } \\
\text { hardness \& an increase of } 5.4 \% \text { in roughness }\end{array}$ & {$[12]$} \\
\hline $\begin{array}{l}\text { Phenolic resin }(\mathrm{PF}) \text { /organized expanded } \\
\text { vermiculite }(\mathrm{OEVMT})\end{array}$ & $\begin{array}{l}\text { (i) The brake pad based on PF exhibited a weight reduction ratio of } 45.8 \% \text {, } \\
\text { whereas the brake pad based on PF/OEVMT exhibited a ratio of } 77.1 \% \\
\text { (ii) For the PF/OEVMT brake pad, the coefficient of friction decreased by } \\
\text { only } 0.05 \text {, whereas for the PF based brake pad, the value decreased by } 0.24\end{array}$ & [39] \\
\hline Kaolin- $\mathrm{TiO}_{2}$ (KATI) & $\begin{array}{l}\text { (i) The loss of pad thickness was } 50 \% \text { lower for the KATI-based brake pad } \\
\text { which improved the durability }\end{array}$ & {$[13]$} \\
\hline Boron & $\begin{array}{l}\text { (i) The coefficient of friction for the boron-based brake pad was } 0.065 \text { higher } \\
\text { than its counterpart }\end{array}$ & {$[41]$} \\
\hline Graphene/boron nitride with aluminum & $\begin{array}{l}\text { (i) Sample Al-1BN-0.15GNP exhibited an increase of } 225 \% \text { in ultimate } \\
\text { compressive strength \& an } 87 \% \text { increase in hardness values }\end{array}$ & {$[42]$} \\
\hline $\begin{array}{l}\text { Aluminum-silicon nitride }\left(\mathrm{Al}-\mathrm{Si}_{3} \mathrm{~N}_{4}\right) \& \\
\text { aluminum-graphite-silicon nitride }\left(\mathrm{Al}-\mathrm{Gr}-\mathrm{Si}_{3} \mathrm{~N}_{4}\right)\end{array}$ & $\begin{array}{l}\text { (i) For the Al-Gr-Si } \mathrm{N}_{4} \text { sample, the wear rate decreased by } 25 \% \text { when } \\
\text { compared with the } \mathrm{Al}-\mathrm{Si}_{3} \mathrm{~N}_{4} \text { sample } \\
\text { (ii) There was a reduction of } 15 \% \text { in the friction coefficient of the Al-Gr- } \\
\mathrm{Si}_{3} \mathrm{~N}_{4} \text { sample when compared with the } \mathrm{Al}-\mathrm{Si}_{3} \mathrm{~N}_{4} \text { sample }\end{array}$ & {$[45]$} \\
\hline $\mathrm{Al} / \mathrm{SiC}+\mathrm{B}_{4} \mathrm{C}$ & $\begin{array}{l}\text { (iii) Wear resistance increased by } 88.32 \% \text { for the sample containing } 1.5 \% \mathrm{SiC} \\
\& 0.5 \% \mathrm{~B}_{4} \mathrm{C} \text { as compared with a monolithic aluminum }\end{array}$ & {$[14]$} \\
\hline
\end{tabular}

TABLE 7: Parameters on which different nanomaterials are assessed.

\begin{tabular}{|c|c|c|c|c|}
\hline Material & \multicolumn{3}{|c|}{ Parameters } & Reference \\
\hline Hazelnut shell & - & 0.548 & 92 shore $\mathrm{D}$ & {$[3]$} \\
\hline Boron dust & - & 0.508 & 95 shore $\mathrm{D}$ & {$[3]$} \\
\hline Palm kernel fiber & $4.4 * 10^{-4}(\mathrm{~g} / \mathrm{m})$ & 0.43 & 2.98 HRA & {$[4]$} \\
\hline Bagasse ash & $13\left(10^{-7} \mathrm{~cm} / \mathrm{Nm}\right)$ & 0.55 & $118 \mathrm{HV}$ & {$[89]$} \\
\hline Fly ash & $10\left(10^{-7} \mathrm{~cm} / \mathrm{Nm}\right)$ & 0.62 & $118 \mathrm{HV}$ & {$[89]$} \\
\hline Bagasse additive (5 wt $\%)$ & $1.2 * 10^{-6}(\mathrm{~g} / \mathrm{m})$ & 0.36 & $94 \mathrm{HB}$ & {$[38]$} \\
\hline PF/OEVMT nanocomposite & $0.25 * 10^{-7} \mathrm{~cm}^{3} / \mathrm{Nm}$ & 0.45 & - & {$[39]$} \\
\hline Crab shell powder & - & 0.385 & 106 HRS & {$[47]$} \\
\hline Cf@RTVSR & $0.62 * 10^{-9} \mathrm{~cm}^{3} / \mathrm{J}$ & 0.3414 & - & {$[90]$} \\
\hline Banana peel powder ( $7 \mathrm{wt} \%)$ & $0.064 \mathrm{~g}$ & 0.425 & - & {$[30]$} \\
\hline $\mathrm{Al}-\mathrm{Gr}$ & $0.0432 \mathrm{~mm}^{3} / \mathrm{km}$ & 0.35 & $74.6 \mathrm{HV}$ & {$[45]$} \\
\hline $\mathrm{Al}-\mathrm{Si}_{3} \mathrm{~N}_{4}$ & $2.298 \mathrm{~mm}^{3} / \mathrm{km}$ & 0.425 & $78.5 \mathrm{HV}$ & {$[45]$} \\
\hline $\mathrm{Al}-\mathrm{Gr}-\mathrm{Si}_{3} \mathrm{~N}_{4}$ & $1.123 \mathrm{~mm}^{3} \cdot \mathrm{km}^{-1}$ & 0.345 & $91.3 \mathrm{HV}$ & {$[45]$} \\
\hline $\mathrm{Al} / \mathrm{Al}_{2} \mathrm{O}_{3}$ composite & 11 microns $/ \mathrm{km}$ & 0.375 & - & {$[46]$} \\
\hline $\mathrm{Cu}-\mathrm{Sn}$ & $0.05 \mathrm{~cm}^{3} / \mathrm{MJ}$ & 0.392 & $130.6 \mathrm{HV}$ & {$[84]$} \\
\hline Corn stalk fiber & $0.3 * 10^{-7} \mathrm{~cm}^{3} / \mathrm{Nm}$ & 0.425 & - & {$[87]$} \\
\hline Fused mullite & $0.887 \mathrm{~g}$ & 0.592 & $83.5 \mathrm{HRL}$ & {$[88]$} \\
\hline Basalt fiber (15 wt\%) & $0.23 * 10^{-7} \mathrm{~cm}^{3} / \mathrm{Nm}$ & 0.761 & $68 \mathrm{HRM}$ & {$[91]$} \\
\hline Carbon fiber (0.4 wt $\%)$ & $0.224 \mathrm{~cm}^{3} / \mathrm{MJ}$ & 0.364 & $24.1 \mathrm{HB}$ & {$[92]$} \\
\hline Recycled carbon fiber & $3.8 \mu \mathrm{m} \cdot \mathrm{min}^{-1}$ & 0.4 & - & [93] \\
\hline
\end{tabular}


TABLe 8: Apparatus to test the tribological and thermal properties.

\begin{tabular}{ll}
\hline Parameter tested & Apparatus \\
\hline Wear rates \& wear resistance & (i) Pin-on-disk \\
& (i) Chase machine \\
Friction \& wear characteristics & (ii) Krauss-type tester \\
& (iii) Dry sliding wear tests \\
Characterization \& visualization of surface morphology & (v) 1/5-scale brake dynamometer \\
Structural \& chemical characterization & (i) Scanning electron microscope \\
Grain size \& structure & (i) Transmission electron microscope \\
Surface composition & (i) X-ray diffraction \\
Wear test & (i) Fourier transform infrared spectroscopy \\
Thermal analysis & (i) Reciprocating friction monitor \\
\hline
\end{tabular}

method revealed that BP10 samples had the highest wear rate, whereas BP5/BG5 samples depicted the lowest values [38]. Superior thermal characteristics of the PF/OEVMTbased brake pad were confirmed by thermogravimetric analysis. The PF/OEVMT brake pad exhibited stable friction and lower wear rates compared with the PF brake pad. A significant increase in wear resistance at high temperatures was depicted by the PF/OEVMT-based brake pad [39]. Samples containing OEVMT+ $\mathrm{TiO}_{2}$ and OEVMT+ZnO improved the resistance to thermal cracking. Sample OEVMT+SiO exhibited the highest rutting resistance. Sample $\mathrm{OEVMT}+\mathrm{ZnO}$ exhibited the highest cracking resistance. Maximum resistance to aging was depicted by OEVMT+$\mathrm{TiO}_{2}$ followed by OEVMT $+\mathrm{ZnO}$ and finally OEVMT $+\mathrm{SiO}_{2}$ samples. The $1 \% \mathrm{OEVMT}+2 \% \mathrm{TiO}_{2}$ sample was considered to be ideal based on various assessments [40]. The durability of the brake pad based on the kaolin/ $/ \mathrm{TiO}_{2}$ nanocomposite was significantly improved compared with that of commercial brake pads. The thermal stability of the brake pad based on the KATI nanocomposite was higher when analyzed with the help of the EDS apparatus [13]. The average value of the coefficient of friction for a boron-based brake pad was higher than its commercially available counterpart. Phenomena of fade were more prominent in commercial brake pads as compared to boron-based brake pads. The boronbased brake pad was more stable than its commercially available counterpart [41]. As superior mechanical properties were exhibited by 1 weight $\%$ boron nitride, it was chosen to investigate the effect of graphene on the strength of the aluminum-boron nitride-graphene (Al-BN-GNP) composite. The Al-1BN-0.15GNP composite exhibited $2.63 \pm 0.01$ $\mathrm{g} / \mathrm{cm}^{3}$ density, $2.6 \%$ porosity, $58 \pm 1.5 \mathrm{HV}$ hardness, and $260 \mathrm{MPa}$ of ultimate strength. Results indicated that the Al-BN-GNP composite demonstrated very high mechanical characteristics and is capable of industrial applications [42]. The greater mass loss resulted from the $\mathrm{Al}-\mathrm{Si}_{3} \mathrm{~N}_{4}$ composite when compared with the $\mathrm{Al}-\mathrm{Gr}-\mathrm{Si}_{3} \mathrm{~N}_{4}$ composite. The same was the addition of graphite which exhibited good bonding strength and also exhibited a higher value for hardness. The wear rate also decreased significantly for the Al$\mathrm{Gr}-\mathrm{Si}_{3} \mathrm{~N}_{4}$ sample when compared with the Al-Si $\mathrm{N}_{3}$ sample.
The friction coefficient was also less in the Al- $-\mathrm{Gr}_{-} \mathrm{Si}_{3} \mathrm{~N}_{4}$ composite, which explains less wear rates [45]. SEM confirmed the uniform distribution of hybrid nanoconstituents. As the content of the particles increased, the hardness of the nanocomposites also increased. Wear resistance was significantly improved for samples containing $0.5 \mathrm{wt} \% \mathrm{~B}_{4} \mathrm{C}$ and $1.5 \mathrm{wt} \% \mathrm{SiC}$ compared with aluminum. The coefficient of friction was in the expected range for all samples [14]. Except for coconut shell and coconut fiber, all fibers were treated chemically to enhance their properties. The great potential was exhibited by kenaf to be used as a filler material, whereas palm kernel exhibited its capability to reinforce the brake pad [49]. Naturally occurring coconut fiber was studied. Four different samples containing different volume fractions of coconut fiber were prepared and analyzed. The parameters that were analyzed included specific gravity, porosity, hardness, and compressive strength. Scanning electron microscopy was used to examine the microstructure of the composite along with its constituents. High density and low porosity were exhibited by the samples containing 5 and $10 \%$ content of the coconut fiber. The sample's higher strength was exhibited with $10 \%$ coconut fiber to handle high loads and hold high compressive forces. Investigation of the surface morphology revealed a homogeneous distribution of the fiber in the matrix [94]. The addition of nanoadditives reduces the frictional vibrations caused by the humid conditions, thereby reducing noise generated during operation [95]. This study investigated the effect of corn stalk fiber prepared by wet granulation and used as a friction material in brake pads. Samples containing different wt\% were analyzed. The fade and recovery test results indicated that the sample with $7 \mathrm{wt} \%$ exhibited minimum fade ratios, maximum recovery ratios, and lower fluctuations in fade and recovery and better resistance to wear [87]. Results indicated that the sample containing $7 \mathrm{wt} \%$ mullite (HC3) exhibited the highest hardness and specific gravity, followed by the sample containing $5 \%(\mathrm{HC} 2)$ and $3 \%$ mullite $(\mathrm{HC} 1)$, respectively. Sample HC1 exhibited the highest heat swell and loss on ignition, whereas opposite characteristics were shown by HC3. The highest porosity was shown by HC1, whereas HC3 exhibited the lowest porosity. Sample HC1 containing $3 \mathrm{wt} \%$ 
TABLE 9: Carbon nanomaterials suitable for braking applications.

\begin{tabular}{lll}
\hline Research purpose & $\begin{array}{l}\text { Constituents of } \\
\text { brake friction } \\
\text { material used }\end{array}$
\end{tabular} Inferences $\quad \begin{aligned} & \text { Ref. } \\
& \text { no. }\end{aligned}$

\begin{tabular}{|c|c|c|c|}
\hline $\begin{array}{l}\text { Analysis of tribological properties of friction } \\
\text { materials pertaining CNTs }\end{array}$ & $\begin{array}{l}\text { (i) Resin } \\
\text { (ii) Kevlar } \\
\text { (iii) Barite } \\
\text { (iv) Zircon } \\
\text { (v) Graphite } \\
\text { (vi) CNT }\end{array}$ & $\begin{array}{l}\text { (i) Increased CNT content improves the wear resistance and } \\
\text { damping ability making it better for high performance and } \\
\text { vigorous use } \\
\text { (ii) However, with this increase, COF and thermal } \\
\text { conductivity decreased, which reduces the braking } \\
\text { performance of the materials } \\
\text { (iii) By manipulating the abrasive and filler content, } \\
\text { improving the COF of the material makes it viable for } \\
\text { braking applications }\end{array}$ & [16] \\
\hline
\end{tabular}

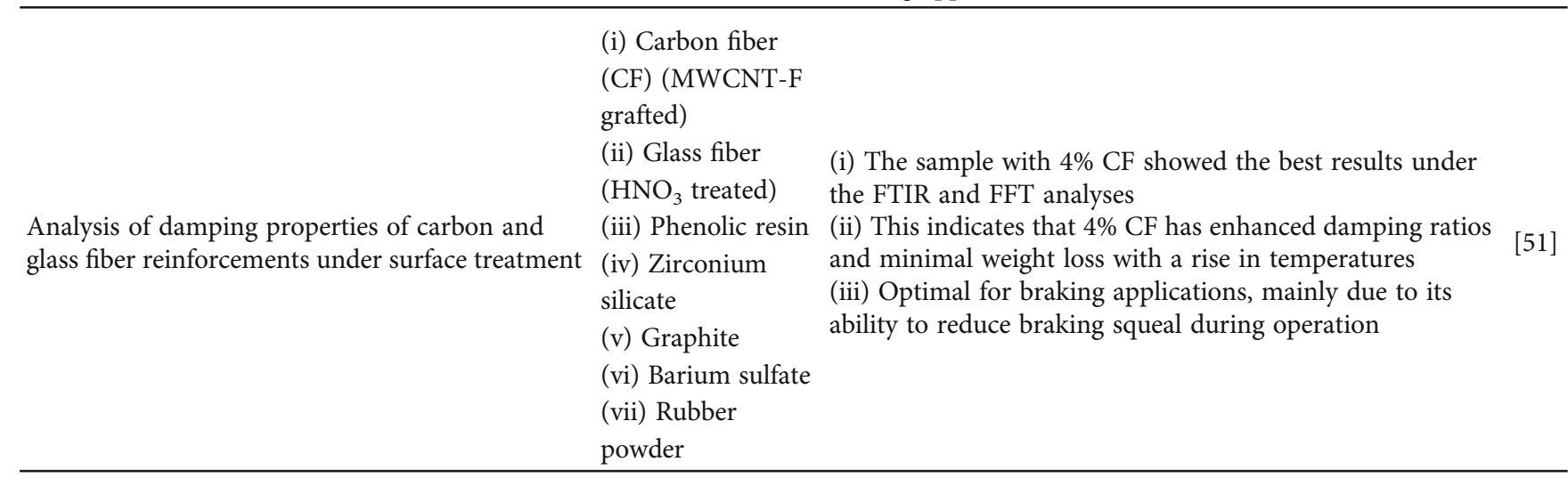

(i) Carbon fibe

(ii) Glass fiber $\left(\mathrm{HNO}_{3}\right.$ treated) the FTIR and FFT analyses

Analysis of damping properties of carbon and (iii) Phenolic resin silicate

(i) The hybrid composites displayed a stable COF of 0.6 at room temperature, agreeing with the SAE norms

(i) $\mathrm{CNT}$

(ii) Aluminum

(ii) But with an increase in temperature $\left(450^{\circ} \mathrm{C}\right)$, only the

GC composite is stable with a COF of 0.5

Tribological analysis of $\mathrm{Al}-\mathrm{SiC}(n)$ hybrid composites with the inclusion of carbon

(iii) Silicon carbide composite is 10 times harder than the regular composite

(iv) Glassy carbon and twice harder than the GC composite

(iv) The addition of carbon nanomaterials with optimized compositions can help supplement the tribological properties of brake friction materials

(i) The addition of CNTs has drastically improved the performance of the composite

(i) Epoxy resin

(ii) Short carbon fiber fiber epoxy composites as a friction material for brake pads (iii) MWCNT (ii) Pads show a significant increase of 5-20\% in wear resistance than the non-CNT composite

(iii) Thermal stability is also found to increase with the addition of CNTs while consecutively increasing carbon fiber content

(i) Pads with CNS showed industry-standard mechanical behavior with increased compressive strength and impact

(i) Graphite nanoparticles

(ii) Epoxy resin

Analysis of thermal and mechanical behaviors of biobased nanomaterial for braking operations

(iii) Carbon nanospheres (CNS) (iv) Stainless stee nanoparticles resistance than the conventional one

(ii) CNS pads also displayed enhanced damping and reduced wear loss, making them optimal for the braking application

(iii) The addition of CNS to the resins also augments the thermal stability of the pad; however, it is still less than the conventional one

(iv) CNS has a scope in braking applications to improve thermal stability, which is usually lacking in many carbon nanomaterial-based brake pads (i) Epoxy resin

(ii) Carbon fiber

(iii) MWCNT (i) HNC pads exhibited improved mechanical properties compared to conventional brake pads, with both having COF ranging from 0.39 to 0.41
Study of hybrid nan
brake pad material 
TABLE 9: Continued.

\begin{tabular}{lll}
\hline Research purpose & $\begin{array}{l}\text { Constituents of } \\
\text { brake friction } \\
\text { material used }\end{array}$ & $\begin{array}{l}\text { Ref. } \\
\text { Inferences }\end{array}$ \\
\hline $\begin{array}{ll}\text { (iv) Graphite } \\
\text { nanopowder }\end{array}$ & $\begin{array}{l}\text { (ii) HNC also displayed 90\% lesser braking distance, pad } \\
\text { wear, surface temperature, and noise levels when compared } \\
\text { to the conventional ones } \\
\text { (iii) The addition of CNTs also showed an increase in COF } \\
\text { and a decrease in braking distance, making it optimal for } \\
\text { braking applications } \\
\text { (iv) However, further work must be carried out with regard } \\
\text { to the thermal stability to optimize the material }\end{array}$ \\
\hline
\end{tabular}
to the thermal stability to optimize the material

(i) Higher CNT and nanoclay content augmented the frictional properties of the composite

(i) $\mathrm{PF}$

Study of the effects of nanoclay and CNT on the tribological performance of nanofilled hybrid phenolic composites (ii) Barium sulfate

(iii) Kevlar fiber

(iv) Nanoclay

(v) MWCNT

(vi) Graphite

(ii) These composites adhered to the industry norms, with the COF ranging from 0.3 to 0.3

(iii) Having higher CNT and nanoclay content also enhanced the composite's thermal stability, fade, and recovery behavior

(iv) This study shows that the addition of carbon nanomaterials to existing composites, with proper reinforcement and fillers, helps to improve the friction performance of the material

(i) The COF of both HNC and conventional pads ranged

(i) Epoxy resin

(ii) Carbon fiber (CF)

To study the frictional and wear properties of polymer hybrid nanocomposites (iii) MWCNT

(iv) Graphite

nanopowder from 0.39 to 0.41 , adhering to the industrial standards (ii) HNC showed enhanced tribological performance with shorter braking distance and time and reduced wear rates (iii) An increase in CF content in the composite leads to increased COF and a decrease in stopping resistance

(iv) By changing the number of constituents and nanomaterials being added, the composite can be manipulated to achieve the desired properties

mullite was considered an optimal sample [88]. The study is aimed at evaluating the potential performance of the composites with different contents of basalt fibers. Bas-15 (15\% of basalt fiber) depicted the best mechanical properties. Bas- 0 and Bas- 15 samples showed the optimum value for the coefficient of friction. The sample containing $15 \%$ of basalt fiber (Bas-15) was considered optimal based on the tests conducted. Klapiszewski et al. studied the characteristics of magnesium lignosulfonate and kraft lignin by oxidizing them for utilizing phenolic resins for producing abrasives for commercial brake pads [96]. It was found that when sodium peroxide and hydrogen peroxide were used as oxidizing agents, the samples oxidized by the latter showed more homogeneity. Out of all the samples, hydrogen peroxide oxidized $5 \%$ of magnesium lignosulfonate and showed the best thermomechanical properties and therefore showed good potential for future commercial usage.

3.2. Carbon Nanomaterials in Brake Pads. The utilization of carbon nanomaterials to formulate a friction material for brake pads helps to manipulate the properties of the pads by varying the amounts of nanomaterials used [97, 98]. Given the larger surface area of carbon nanomaterials, the addition of small quantities of nanomaterials can bring about considerable change to the tribological properties of the composites [99]. Many researchers utilize this property to develop different materials and optimize materials for the required tribological properties. The most commonly used carbon nanomaterial includes the multiwalled carbon nanotubes (MWCNT) and epoxy and phenolic resin matrix and reinforcements, as seen in Table 6 [100]. Hwang et al. tested the MWCNT-based composite, formulated through the dry mixing method through an Eirich mixer [16] at room temperature and molded at elevated temperatures for 10 minutes. The friction test carried out through the Krauss-type tester showed that increasing the amount of $\mathrm{CNT}$ in the composite resulted in an increase in the frictional stability and strength at elevated temperatures. Abhik and Umasankar investigated the role of carbon fiber and $\mathrm{SiC}$ powder additions in improving the strength and wear resistance of the brake pad composite, respectively [101]. It has been found that with an increase in these additions, there is improvement observed in the strength and wear resistance of the samples, whereas a high amount of $\mathrm{SiC}$ leads to agglomeration of carbides, ultimately resulting in poor performance. Zhang et al. investigated the effect of the inclusion of nanocarbon fibers in $\mathrm{Cu}$-based brake pads [92]. It was found that this has a positive effect on tribofilm microhardness and resistance to plastic deformation. In addition to this, it is found that nanocarbon fibers have higher specific energy than graphite and, as a result, react efficiently with iron to form cementite, thus providing more support and 


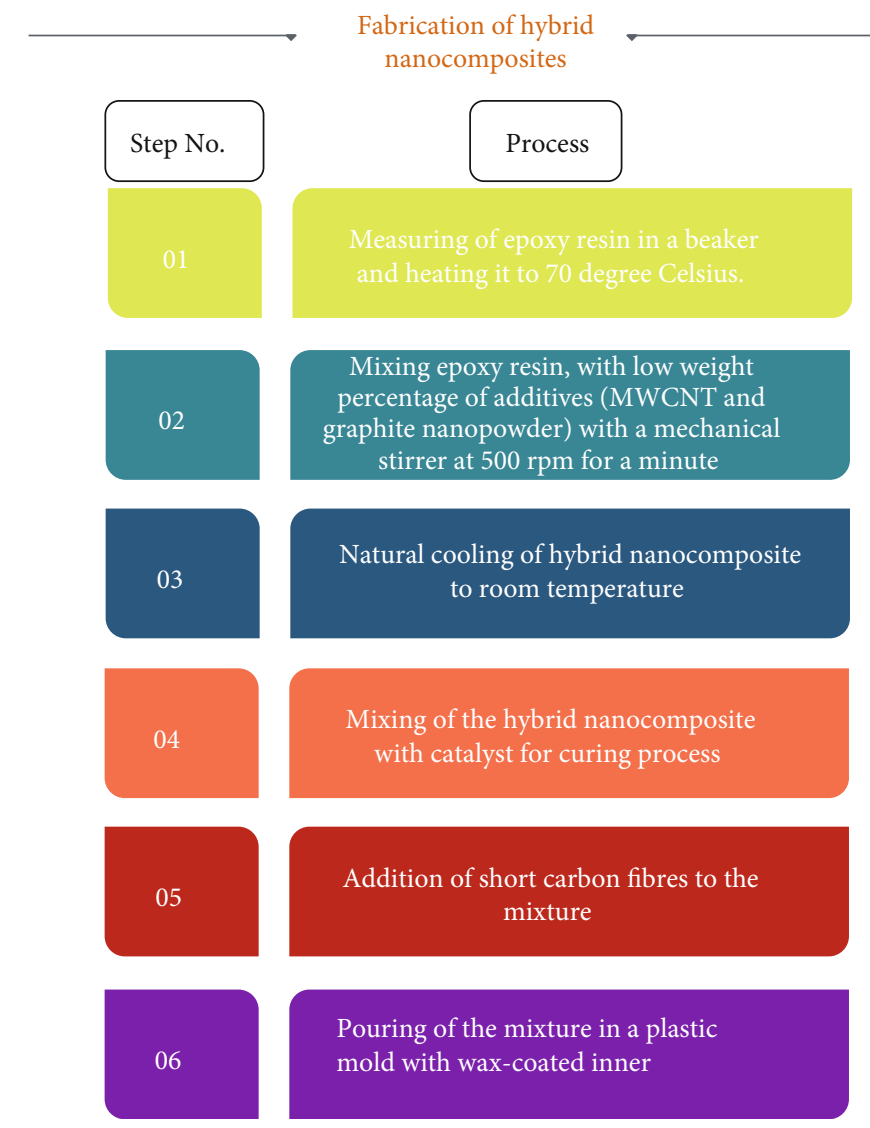

FIGURE 10: Steps for the formation of hybrid nanocomposites.

Steps for the fabrication of nanoclay composite

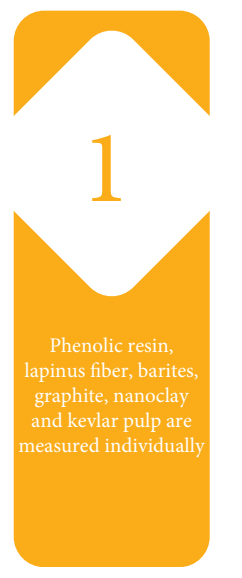

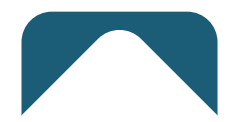

2

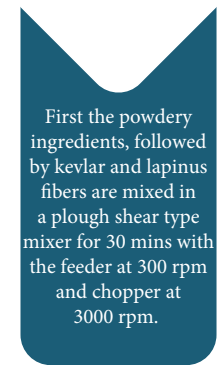

FIGURE 11: Steps for the formation of the nanoclay composite.

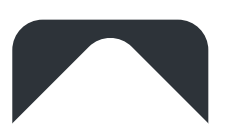

3

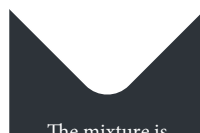

The mixture is

transferred to mould

cavities for curing at
a temperature of 155

a temperature of 155
degree Celsius and

compressive

pressure of $15 \mathrm{MPa}$

for 10 mins

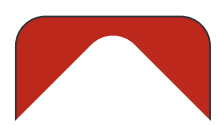

4

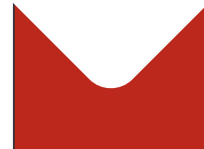

Post the curing

process, the mixture

kept at a temperature

150 degree Cels

for 5 hours.

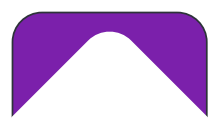

5

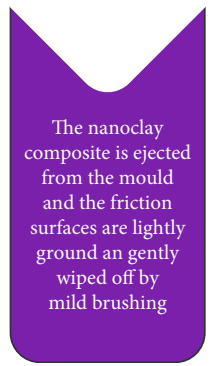

stability to the friction surface. Faga et al. investigated the factors affecting the carbon nanomaterials for brake pad applications in morphology, structural rigidity, and frictional characteristics [102]. The study implied that the use of spherically shaped materials helps in reinforcing the lubricating effect, as it is easier to roll on them. In addition, it was found that with reduced dimensions of the object used, the friction is reduced due to the high density of particles at the interface. On the same lines, Table 8 highlights some of the most commonly used testing methodologies for testing various tribological and surface properties of the brake pad materials, obtained from the literature review.

In addition to the above, Table 9 includes some of the most popularly studied combinations of commercial brake pad applications with the incorporation of carbon nanomaterials. This could help in future works focusing on the 
TABLE 10: Future prospects and challenges of carbon nanomaterials.

\begin{tabular}{|c|c|}
\hline Future prospects & $\begin{array}{l}\text { (i) Improved wear resistance } \\
\text { (ii) Enhanced damping ability } \\
\text { (iii) Enhanced damping ratio } \\
\text { (iv) Minimal weight loss } \\
\text { (v) Stable COF } \\
\text { (vi) Increased thermal stability } \\
\text { (vii) Increased compressive strength } \\
\text { (viii) Increased impact resistance } \\
\text { (ix) Decreased braking distance } \\
\text { (x) Lower noise levels }\end{array}$ \\
\hline Challenges & $\begin{array}{l}\text { (i) Release of wear particles } \\
\text { (ii) Carcinogenic effect } \\
\text { (iii) Hard to degrade which in turn harms the environment } \\
\text { (iv) Soil fertility is affected } \\
\text { (v) Toxic compounds are released }\end{array}$ \\
\hline
\end{tabular}

studies involving future potential commercial brake pad materials.

Gbadeyan and Kanny worked with MWCNT to create a hybrid nanocomposite (HNC) for braking applications [21]. The HNC is formulated by mixing MWCNT, epoxy resin, and other constituents (Table 9) using a mechanical stirrer at $500 \mathrm{rpm}$ for 60 minutes. The steps to be followed for the production of hybrid nanocomposites for brake pad applications have been shown in Figure 10 for better elucidation and comprehensibility, and Figure 11 shows the methodology of formulation of nanoclay, one of the most important emerging materials for use in commercial brake pads. The homogeneous mixture formed is then cooled to room temperature, cured, and then molded to the desired shape. The main tribological properties of the HNC are analyzed using the inertial dynamometer test, and then the results are compared with that of commercially available brake pads. This study showed that increasing carbon fiber content enhanced the COF and braking distance and the overall tribological properties. Ige et al. formulated an HNC brake pad containing carbon nanospheres by mixing the constituents (Table 9) using a mechanical stirrer [54]. The mixture is cooled to room temperature and then sent for curing for 14 days. This HNC showed a uniform carbon nanosphere distribution and high compressibility. Mainly, this HNC brake pad showed good thermal stability. Although lower than the conventional brake pad, the overall result is good as pads based on carbon nanomaterials do not have high thermal stability. Guo et al. investigated the characteristics and frictional performance of $\mathrm{C}-\mathrm{C} / \mathrm{SiC}$ materials made from recycled carbon fiber felt and found that they hold high potential for utilization as alternative commercial brake pad substances [93].

An innovative carbon nanocomposite is a bambooCNT-PEEK composite with synthetic diamonds. This composite is formulated by the hot sintering technique, producing a homogenous mixture of the composite with high density. Probe sonication helps disperse the bamboo-CNT and synthetic diamonds into the PEEK matrix. The composite is analyzed, and the results depict high thermal stability and reduced wear rates. Although the coefficient of friction is lesser than usual, it is still applicable for braking opera- tions. Overall, carbon nanomaterials provide freedom to manipulate and optimize the friction material's properties to suit individual needs and applications, making it a viable option for brake pads.

Another essential factor to consider with the utilization of carbon nanomaterials in brake pads is the effect of wear particles released during operation on the human body and the environment. Nanoparticles accumulate and aggregate over time, leading to harmful effects on the environment and the human body $[103,104]$. CNTs, depending on their inherent properties, can also display this effect and have a toxic effect on the lungs, liver, spleen, and heart [70, 105]. MWCNTs, upon acute exposure, can damage the lung tissues and have harmful effects on one's health [106, 107]. So it becomes essential to check the effects of wear particles released into the air on the human body, especially the lungs, as it is the main point of accumulation for this case. Even though carbon nanocomposite pads have lower wear rates than conventional pads, the overall accumulation of particles can be harmful. Hence, even if carbon nanomaterials become a viable alternative for brake pads in the future, they will lose all their value once they turn harmful. Overall, the major future prospects and challenges of the utilization of carbon nanomaterials for brake pad applications obtained through this literature are discussed in Table 10.

\section{Summary and Conclusions}

Brake pad materials need to satisfy several properties such as lower wear rates, less noise, improved damping, friction stability, and thermal stability. In lieu of this, materials used in the commercial brake pads have moved from asbestos to complex metal matrix composites. While the use of asbestos, metallic, semimetallic, and NAO materials is advantageous in some aspects, none of the currently used materials exhibit all the required properties at desired levels. For instance, NAO brake pads generate lower noise but easily wear off, while for the metallic brake pads, it is vice versa. Further, studies dealing with the addition of nanomaterials such as banana peel powder and crab shell powder in relatively small amounts to existing composites were carried out, and they 
were found to exhibit much better performance in terms of wear rates, durability, compressibility, COF, and weight reduction, as depicted in Table 6.

Along the same lines, carbon nanomaterials are also studied and analyzed for their application in brake pads. Even a small amount (0.5-5\%) of the addition of carbon nanomaterials was found to dramatically enhance the properties of brake pads, making them a viable option. This is because the addition of carbon nanomaterials to composites creates a higher interfacial surface area, improving the damping wear resistance, damping factor, and frictional stability. They were also observed to provide flexibility to manipulate the tribological properties of the composite by varying its constituents, thus improving their hardness, stiffness, and compressibility. Also, it was found that with an increase in carbon nanomaterial content, there is an increase in COF, frictional stability, and wear resistance while decreasing the thermal stability (Table 9). Additionally, among carbon nanomaterials, hybrid nanocomposites with MWCNT are among the leading choices for a viable alternative to commercially available brake pads for their ease of formulation and accessibility.

Although the use of nanomaterials seems very advantageous, it poses a major disadvantage that questions their feasibility. With the use of brake pads made of carbon nanomaterials, attention should also be given to the effects of wear particles released during their operation and their potential impact on the environment. The characteristics of nanomaterials allow them to easily bind with other molecules to form new compounds which are not easily degradable. Consequently, they can reduce soil fertility, aggregate on water bodies, and combine with existing pollutants to form toxic compounds. In the case of CNTs, in addition to their potential danger to the environment, they pose a major health hazard for humans due to their toxicity. Long CNTs are found to be carcinogenic and depict similar effects as that of asbestos on living beings.

From the review conducted, it is observed that although these nanomaterials are indeed emerging to be an extremely beneficial alternative to current brake pad materials, there still needs to be more research carried out on obtaining and manufacturing various carbon nanomaterials for brake pad application. In addition, there is a severe lack of research on determining the interactions between the wear debris and the environment. This is an important field of study requiring more research as the results will decide the feasibility of the utilization of carbon nanomaterials for future commercial braking applications. Lastly, studies should also focus on improving and optimizing the thermal stability of carbon nanocomposites as they are still much lower than the conventional brake pad materials.

\section{Abbreviations}

$\begin{array}{ll}\text { BG: } & \text { Bagasse particle } \\ \text { BN: } & \text { Boron nitride } \\ \text { BP: } & \text { Banana peel particles } \\ \text { CBS: } & \text { Crab shell } \\ \text { CF: } & \text { Carbon fiber }\end{array}$

CMAI: Complex modulus aging index

CNCs: Carbon nanocomposites

CNS: Carbon nanospheres

CNTs: Carbon nanotubes

COF: Coefficient of friction

DOT: Department of Transportation

DSC: Differential scanning calorimetry

DSRFn: Dynamic shear rheometer

EDS: $\quad$ Energy-dispersive X-ray spectroscopy

FTIR: $\quad$ Fourier transform infrared spectroscopy

GNP: Graphene nanoplatelets

HNC: $\quad$ Hybrid nanocomposites

KATI: Kaolin- $\mathrm{TiO}_{2}$

LAS: $\quad$ Linear amplitude sweep

MMCs: $\quad$ Metal matrix composites

MSCR: Multiple stress creep recovery

MWCNTs: Multiwalled carbon nanotubes

NAO: Nonasbestos organic

OEVMT: Organized expanded vermiculite

PEEK: $\quad$ Polyether ether ketone

PF: $\quad$ Phenolic resin

PM: $\quad$ Powder metallurgy

SEM: $\quad$ Scanning electron microscopy

SSR: $\quad$ Shear-stress relaxation

SWCNTs: Single-walled carbon nanotubes

TEM: Transmission electron microscopy

TENG: Triboelectric nanogenerator

TGA: Thermogravimetric analysis

XRD: $\quad \mathrm{X}$-ray diffraction analysis.

\section{Conflicts of Interest}

The authors declare that they have no conflicts of interest.

\section{References}

[1] S. Kumar and S. K. Ghosh, "Particle emission of organic brake pad material: a review," Proceedings of the Institution of Mechanical Engineers, Part D: Journal of Automobile Engineering, vol. 234, no. 5, pp. 1213-1223, 2020.

[2] R. Arvind Singh, S. Jayalakshmi, S. Sankaranarayanan et al., "Tribological characteristics of magnesium nanocomposites," Materials Today: Proceedings, vol. 5, no. 8, pp. 16575-16579, 2018.

[3] G. Akıncioğlu, H. A. S. A. N. Öktem, I. Uygur, and S. Akıncıoğlu, "Determination of friction-wear performance and properties of eco-friendly brake pads reinforced with hazelnut shell and boron dusts," Arabian Journal for Science and Engineering, vol. 43, no. 9, pp. 4727-4737, 2018.

[4] S. Pujari and S. Srikiran, "Experimental investigations on wear properties of palm kernel reinforced composites for brake pad applications," Defence Technology, vol. 15, no. 3, pp. 295-299, 2019.

[5] D. S. E. A. Chan and G. W. Stachowiak, "Review of automotive brake friction materials," Proceedings of the Institution of Mechanical Engineers, Part D: Journal of Automobile Engineering, vol. 218, no. 9, pp. 953-966, 2004.

[6] T. Singh, A. Patnaik, and B. K. Satapathy, "Effect of carbon nanotubes on tribo-performance of brake friction materials," 
AIP Conference Proceedings, vol. 1393, no. 1, pp. 223-224, 2011.

[7] W. Österle and A. I. Dmitriev, "Functionality of conventional brake friction materials - Perceptions from findings observed at different length scales," Wear, vol. 271, no. 9-10, pp. 21982207, 2011.

[8] N. K. Konada and S. K. N. Sai, "Effect of surface treatments on damping behaviour of carbon fibre reinforced brake friction material," International Journal of Automotive Composites, vol. 4, no. 2, pp. 96-113, 2019.

[9] G. Macías, C. Lorenzana, and J. Fernandez, "Determination of diffusion capability of oxygen through brake pads from the surface towards the interior," SAE International Journal of Advances and Current Practices in Mobility, vol. 3, no. 2, pp. 940-947, 2021.

[10] M. Qingrui, W. Dagang, and T. Qing, “Uneven distribution characteristics of contact force of large-sized non-asbestos brake pad," Advances in Mechanical Engineering, vol. 10, no. 5, Article ID 1687814018776059, 2018.

[11] X. Ma, C. Luan, S. Fan, J. Deng, L. Zhang, and L. Cheng, "Comparison of braking behaviors between iron- and copper-based powder metallurgy brake pads that used for C/C-SiC disc," Tribology International, vol. 154, article 106686, 2021.

[12] M. Ali, I. Alshalal, A. A. Abtan, A. R. Yousif, and J. H. Mohmmed, "Effect of nano-sized $\mathrm{SiO}_{2}$ particles addition on the surface roughness and micro hardness of copper-based friction materials," Journal of Mechanical Engineering Research and Developments, vol. 44, no. 2, pp. 104-111, 2021.

[13] K. Dědková, M. Morbach, J. Výravský et al., "Nanocomposite $\mathrm{kaolin} / \mathrm{TiO}_{2}$ as a possible functional filler in automotive brake pads," Journal of Nanomaterials, vol. 2018, 14 pages, 2018.

[14] P. Lakshmanan, "Abrasive wear behaviour of aluminium hybrid nanocomposites produced by ultrasonication assisted casting method," International Journal of Automotive \& Mechanical Engineering, vol. 14, no. 3, pp. 4561-4573, 2017.

[15] H. Barosova, S. Chortarea, P. Peikertova et al., "Biological response of an in vitro human $3 \mathrm{D}$ lung cell model exposed to brake wear debris varies based on brake pad formulation," Archives of Toxicology, vol. 92, no. 7, pp. 2339-2351, 2018.

[16] H. J. Hwang, S. L. Jung, K. H. Cho, Y. J. Kim, and H. Jang, "Tribological performance of brake friction materials containing carbon nanotubes," Wear, vol. 268, no. 3-4, pp. 519-525, 2010.

[17] P. J. Harris, "Carbon nanotube composites," International Materials Reviews, vol. 49, no. 1, pp. 31-43, 2004.

[18] A. Singh, T. Ram Prabhu, A. R. Sanjay, and V. Koti, "An Overview of Processing and Properties of CU/CNT Nano Composites," Materials Today: Proceedings, vol. 4, no. 2, pp. 3872-3881, 2017.

[19] K. Vishal, K. Rajkumar, and V. E. Annamalai, "Wear and tribofilm characterization of bamboo CNT (B-CNT)-PEEK composite with incremental blending of submicron synthetic diamond particles," Wear, vol. 466-467, article 203556, 2021.

[20] B. Hekner, J. Myalski, T. Pawlik, and M. Sopicka-Lizer, "Effect of carbon in fabrication Al-SiC nanocomposites for tribological application," Materials, vol. 10, no. 6, p. 679, 2017.

[21] O. J. Gbadeyan and K. Kanny, "Tribological behaviors of polymer-based hybrid nanocomposite brake pad," Journal of Tribology, vol. 140, no. 3, 2018.
[22] 2021. https://idpartsblog.com/2019/04/11what-do-brakepad-friction-ratings-mean/.

[23] G. Malucelli and F. Marino, "Abrasion resistance of polymer nanocomposites-a review," in Abrasion Resistance of Materials (pp. 1-18), Intech Rijeka, Croatia, 2012.

[24] M. S. Balaji and K. Kalaichelvan, "Experimental studies of various reinforcing fibres in automotive disc brake pad on friction stability, thermal stability and wear," International Journal of Materials and Product Technology, vol. 45, no. 1/ 2/3/4, pp. 132-144, 2012.

[25] F. Elhilali, H. Fihri-Fassi, and R. Ourihi, "Towards the development of an optimized numerical model of the brake system pad with natural material," Materials Today: Proceedings, vol. 45, pp. 5419-5425, 2021.

[26] J. Chandradass, P. Baskara Sethupathi, and M. Amutha Surabi, "Fabrication and characterization of asbestos free epoxy based brake pads using carbon fiber as reinforcement," Materials Today: Proceedings, vol. 45, pp. 72227227, 2021.

[27] W. Österle and A. I. Dmitriev, "The role of solid lubricants for brake friction materials," Lubricants, vol. 4, no. 1, p. 5, 2016.

[28] Q. Che, G. Zhang, L. Zhang et al., "Switching brake materials to extremely wear-resistant self-lubrication materials via tuning interface nanostructures," ACS Applied Materials \& Interfaces, vol. 10, no. 22, pp. 19173-19181, 2018.

[29] G. P. Ostermeyer and L. Wilkening, "Experimental investigations of the topography dynamics in brake pads," SAE International Journal of Passenger Cars - Mechanical Systems, vol. 6, no. 3, pp. 1398-1407, 2013.

[30] K. Mausam, A. Sharma, and P. K. Singh, "Calculating stress, temperature in brake pad using ANSYS composite materials," Materials Today: Proceedings, vol. 45, pp. 3547-3550, 2021.

[31] M. Bashir, S. S. Saleem, and O. Bashir, "Friction and wear behavior of disc brake pad material using banana peel powder," International Journal of Research in Engineering and Technology, vol. 4, no. 2, pp. 650-659, 2015.

[32] N. Shandilya, O. Le Bihan, and M. Morgeneyer, "A Review on the Study of the Generation of (Nano)particles Aerosols during the Mechanical Solicitation of Materials," Journal of Nanomaterials, vol. 2014, 16 pages, 2014.

[33] J. Wahlström, L. Olander, and U. Olofsson, "Size, shape, and elemental composition of airborne wear particles from disc brake materials," Tribology Letters, vol. 38, no. 1, pp. 15-24, 2010.

[34] J. D. Fieldhouse and J. Gelb, "New developments of an onvehicle brake pad waste collection system," SAE International Journal of Passenger Cars - Mechanical Systems, vol. 9, no. 3, pp. 1245-1254, 2016.

[35] K. Virmani, C. Deepak, S. Sharma, U. Chadha, and S. K. Selvaraj, "Nanomaterials for automotive outer panel components: a review," The European Physical Journal Plus, vol. 136, no. 9, pp. 1-29, 2021.

[36] P. S. Rawat, R. C. Srivastava, G. Dixit, and K. Asokan, "Structural, functional and magnetic ordering modifications in graphene oxide and graphite by $100 \mathrm{MeV}$ gold ion irradiation," Vacuum, vol. 182, article 109700, 2020.

[37] V. Kumar, "Characterization of various properties of chemically treated Allium sativum fiber for brake pad application," Journal of Natural Fibers, 2020. 
[38] M. Amirjan and H. Sakiani, "The role of natural additives on the wear and friction proper-ties of nanocomposites for friction applications," Mechanics of Advanced Composite Structures, vol. 6, no. 2, pp. 159-165, 2019.

[39] J. Yu, J. He, and C. Ya, "Preparation of phenolic resin/organized expanded vermiculite nanocomposite and its application in brake pad," Journal of Applied Polymer Science, vol. 119, no. 1, pp. 275-281, 2011.

[40] D. Zhang, Z. Chen, H. Zhang, and C. Wei, "Rheological and anti-aging performance of SBS modified asphalt binders with different multi-dimensional nanomaterials," Construction and Building Materials, vol. 188, pp. 409-416, 2018.

[41] A. Muzathik, Y. Nizam, M. Ahmad, and W. Nik, "The effect of boron on the performance of automotive brake," World Journal of Engineering, vol. 10, no. 6, pp. 523-528, 2014.

[42] M. C. Şenel and M. Gürbüz, "Synergistic effect of graphene/ boron nitride binary nanoparticles on aluminum hybrid composite properties," Advanced Composites and Hybrid Materials, pp. 1-13, 2021.

[43] A. M. Muzathik, Y. B. Mohd Nizam, and W. B. Wan Nik, "Effect of boron on friction and temperature characteristics of brake pad materials," Materials Science, vol. 9, no. 12, pp. 481-487, 2013.

[44] J. Wahlström, D. Gventsadze, L. Olander et al., “A pin-ondisc investigation of novel nanoporous composite-based and conventional brake pad materials focussing on airborne wear particles," Tribology International, vol. 44, no. 12, pp. 1838-1843, 2011.

[45] R. Ambigai and S. Prabhu, "Optimization of friction and wear behaviour of $\mathrm{Al}-\mathrm{Si}_{3} \mathrm{~N}_{4}$ nano composite and Al-Gr- $\mathrm{Si}_{3} \mathrm{~N}_{4}$ hybrid composite under dry sliding conditions," Transactions of Nonferrous Metals Society of China, vol. 27, no. 5, pp. 986997, 2017.

[46] M. M. A. Baig, A. M. Al-Qutub, I. M. Allam, F. Patel, and A. S. Mohammed, "Tribological performance of sub-micron $\mathrm{Al}_{2} \mathrm{O}_{3}$-reinforced aluminum composite brake rotor material," Arabian Journal for Science and Engineering, vol. 46, no. 3, pp. 2691-2700, 2021.

[47] D. L. Singaravelu, R. Vijay, S. Manoharan, and M. Kchaou, "Development and performance evaluation of eco-friendly crab shell powder based brake pads for automotive applications," International Journal of Automotive and Mechanical Engineering, vol. 16, no. 2, pp. 6502-6523, 2019.

[48] J. Wen, B. Chen, W. Tang et al., "Harsh-environmental-resistant triboelectric nanogenerator and its applications in autodrive safety warning," Advanced Energy Materials, vol. 8, no. 29, article 1801898, 2018.

[49] S. Yashwhanth, M. Mithun Mohan, R. Anandhan, and S. K. Selvaraj, "Present knowledge and perspective on the role of natural fibers in the brake pad material," Materials Today: Proceedings, vol. 46, pp. 7329-7337, 2021.

[50] C. I. Idumah and S. R. Odera, "Recent advancement in selfhealing graphene polymer nanocomposites, shape memory, and coating materials," Polymer-Plastics Technology and Materials, vol. 59, no. 11, pp. 1167-1190, 2020.

[51] N. Kumar Konada, K. N. S. Suman, and S. Siva Kumar, "Effect of surface treatments on damping behavior of carbon and glass fiber reinforced friction material," Automotive Science and Engineering, vol. 8, no. 1, pp. 2590-2602, 2018.

[52] B. Hekner, J. Myalski, N. Valle, A. Botor-Probierz, M. Sopicka-Lizer, and J. Wieczorek, "Friction and wear behavior of Al-SiC(n) hybrid composites with carbon addition," Composites Part B: Engineering, vol. 108, pp. 291300, 2017.

[53] O. J. Gbadeyan, K. Kanny, and M. Turup Pandurangan, "Tribological, mechanical, and microstructural of multiwalled carbon nanotubes/short carbon fiber epoxy composites," Journal of Tribology, vol. 140, no. 2, 2018.

[54] O. E. Ige, F. L. Inambao, and O. J. Gbadeyan, "Thermomechanical analysis of bio-based hybrid nanocomposites for brake pad application," International Journal of Mechanical and Production Engineering Research and Development, vol. 11, no. 2, pp. 155-170, 2021.

[55] O. J. Gbadeyan, Low friction hybrid nanocomposite material for brake pad application, [Ph.D. thesis], Durban University of Technology, Durban, South Africa, 2017.

[56] T. Singh, A. Patnaik, and B. K. Satapathy, "Friction braking performance of nanofilled hybrid fiber reinforced phenolic composites: influence of nano-clay and carbon nanotubes," Nano, vol. 8, no. 3, article 1350025, 2013.

[57] M. Ghorbani, O. Seyedin, and M. Aghamohammadhassan, "Adsorptive removal of lead (II) ion from water and wastewater media using carbon-based nanomaterials as unique sorbents: a review," Journal of Environmental Management, vol. 254, article 109814, 2020.

[58] M. A. Clark, Effect of nanoparticles on friction and wear of 2$D$ and 3-D carbon-carbon composite disc brakes, Southern Illinois University at Carbondale, 2005.

[59] E. G. Rakov, "Methods for preparation of carbon nanotubes," Russian Chemical Reviews, vol. 69, no. 1, pp. 35-52, 2000.

[60] R. Purohit, A. Mittal, S. Dalela, V. Warudkar, K. Purohit, and S. Purohit, "Social, environmental and ethical impacts of nanotechnology," Materials Today: Proceedings, vol. 4, no. 4, pp. 5461-5467, 2017.

[61] E. Kabir, V. Kumar, K. H. Kim, A. C. Yip, and J. R. Sohn, "Environmental impacts of nanomaterials," Journal of Environmental Management, vol. 225, pp. 261-271, 2018.

[62] A. G. Cattaneo, R. Gornati, E. Sabbioni et al., "Nanotechnology and human health: risks and benefits," Journal of Applied Toxicology, vol. 30, no. 8, pp. 730-744, 2010.

[63] F. Gottschalk and B. Nowack, "The release of engineered nanomaterials to the environment," Journal of Environmental Monitoring, vol. 13, no. 5, pp. 1145-1155, 2011.

[64] M. Baalousha, Y. Yang, M. E. Vance et al., "Outdoor urban nanomaterials: the emergence of a new, integrated, and critical field of study," Science of the Total Environment, vol. 557558, pp. 740-753, 2016.

[65] A. Kazimirova, P. Peikertova, M. Barancokova et al., "Automotive airborne brake wear debris nanoparticles and cytokinesis-block micronucleus assay in peripheral blood lymphocytes: a pilot study," Environmental Research, vol. 148, pp. 443-449, 2016.

[66] O. Nosko, J. Vanhanen, and U. Olofsson, "Emission of 1.3-10 $\mathrm{nm}$ airborne particles from brake materials," Aerosol Science and Technology, vol. 51, no. 1, pp. 91-96, 2017.

[67] C. Liné, C. Larue, and E. Flahaut, "Carbon nanotubes: Impacts and behaviour in the terrestrial ecosystem - A review," Carbon, vol. 123, pp. 767-785, 2017.

[68] A. A. Shvedova, E. R. Kisin, A. R. Murray et al., "Increased accumulation of neutrophils and decreased fibrosis in the lung of NADPH oxidase-deficient C57BL/6 mice exposed to 
carbon nanotubes," Toxicology and Applied Pharmacology, vol. 231, no. 2, pp. 235-240, 2008.

[69] M. Chen, S. Zhou, Y. Zhu et al., "Toxicity of carbon nanomaterials to plants, animals and microbes: recent progress from 2015-present," Chemosphere, vol. 206, pp. 255-264, 2018.

[70] A. Helland, P. Wick, A. Koehler, K. Schmid, and C. Som, "Reviewing the environmental and human health knowledge base of carbon nanotubes," Environmental Health Perspectives, vol. 115, no. 8, pp. 1125-1131, 2007.

[71] Y. Sato, A. Yokoyama, K. I. Shibata et al., "Influence of length on cytotoxicity of multi-walled carbon nanotubes against human acute monocytic leukemia cell line THP-1 in vitro and subcutaneous tissue of rats in vivo," Molecular BioSystems, vol. 1, no. 2, pp. 176-182, 2005.

[72] A. B. Kane, R. H. Hurt, and H. Gao, "The asbestos-carbon nanotube analogy: an update," Toxicology and Applied Pharmacology, vol. 361, pp. 68-80, 2018.

[73] Z. Peng, X. Liu, W. Zhang et al., "Advances in the application, toxicity and degradation of carbon nanomaterials in environment: a review," Environment International, vol. 134, article 105298, 2020.

[74] G. Pan and L. Chen, "Impact analysis of brake pad backplate structure and friction lining material on disc-brake noise," Advances in Materials Science and Engineering, vol. 2018, 9 pages, 2018.

[75] G. Wang and R. Fu, "Impact of brake pad structure on temperature and stress fields of brake disc," Advances in Materials Science and Engineering, vol. 2013, 9 pages, 2013.

[76] Y. Wu, H. Jin, Y. Li, Z. Ji, and S. Hou, "Simulation of temperature distribution in disk brake considering a real brake pad wear," Tribology Letters, vol. 56, no. 2, pp. 205-213, 2014.

[77] N. S. M. Eltayb and A. Hamdy, "Least squares support vector machine approach for predicting frictional performance of industrial brake pad materials," International Journal of Mechanical Engineering and Robotics Research, vol. 7, no. 2, 2018.

[78] H. G. Namgung, J. B. Kim, S. H. Woo et al., "Generation of nanoparticles from friction between railway brake disks and pads," Environmental Science \& Technology, vol. 50, no. 7, pp. 3453-3461, 2016.

[79] M. Sriwiboon, N. Tiempan, K. Kaewlob, and S. K. Rhee, "Changing properties of brake pads and discs during brake testing (no. 2020-01-1628)," 2020, SAE Technical Paper.

[80] K. Mizuta, Y. Nishizawa, K. Sugimoto, K. Okayama, and A. Hase, "Evaluation of friction phenomena of brake pads by acoustic emission method," SAE International Journal of Commercial Vehicles, vol. 7, no. 2, pp. 703-709, 2014.

[81] Z. Wan, X. Liu, Y. Shan, T. He, H. Wang, and G. (Sheng) Chen, "The effect of rigid particle on friction properties of automotive disk brake based on a local modeling," Journal of Tribology, vol. 141, no. 4, 2019.

[82] R. Ciudin, P. C. Verma, S. Gialanella, and G. Straffelini, "Wear debris materials from brake systems: environmental and health issues," WIT Transactions on Ecology and the Environment, vol. 191, pp. 1423-1434, 2014.

[83] P. Zhang, L. Zhang, S. Ren et al., "Effect of matrix alloying of $\mathrm{Fe}$ on friction and wear properties of $\mathrm{Cu}$-based brake pad materials," Tribology Transactions, vol. 62, no. 4, pp. 701711, 2019.

[84] V. V. Kumar, S. S. Kumaran, and S. Dhanalakshmi, "A case study focusing on investigating the tribological performance of Cu-Sn sintered brake pad of off-high road vehicles," Journal of Composite Materials, vol. 54, no. 27, pp. 4299-4310, 2020.

[85] H. Noda and T. Takei, "Analysis of metal pick-up formation process within automotive brake pad," SAE International Journal of Materials and Manufacturing, vol. 13, no. 1, pp. 27-43, 2020.

[86] M. Sriwiboon, S. Rhee, K. Kaewlob, N. Tiempan, and R. Samankitesakul, "A study of pad properties vs. friction, wear and brake squeal: processing/porosity effects," $S A E$ International Journal of Materials and Manufacturing, vol. 10, no. 1, pp. 26-33, 2017.

[87] Y. Liu, L. Wang, D. Liu et al., "Evaluation of wear resistance of corn stalk fiber reinforced brake friction materials prepared by wet granulation," Wear, vol. 432-433, article 102918, 2019.

[88] V. V. Kumar, S. S. Kumaran, S. Dhanalakshmi, and R. Sivaramakrishnan, "Tribological performance evaluation of fused mullite-reinforced hybrid composite brake pad for defence application," Journal of the Brazilian Society of Mechanical Sciences and Engineering, vol. 41, no. 4, pp. 110, 2019.

[89] S. Choosri, N. Sombatsompop, E. Wimolmala, and S. Thongsang, "Potential use of fly ash and bagasse ash as secondary abrasives in phenolic composites for eco-friendly brake pads applications," Proceedings of the Institution of Mechanical Engineers, Part D: Journal of Automobile Engineering, vol. 233, no. 5, pp. 1296-1305, 2019.

[90] T. Yin, Q. Fu, L. Zhou, and Y. Fu, “Carbon fiber @ silicone rubber core-sheath elastomer for enhancing wear- resisting performance of phenolic resin composites," Composites Part B: Engineering, vol. 192, article 107991, 2020.

[91] X. Zhao, J. Ouyang, H. Yang, and Q. Tan, "Effect of basalt fibers for reinforcing resin-based brake composites," Minerals, vol. 10, no. 6, p. 490, 2020.

[92] P. Zhang, L. Zhang, P. Wu et al., "Effect of carbon fiber on the braking performance of copper-based brake pad under continuous high-energy braking conditions," Wear, vol. 458459, article 203408, 2020.

[93] W. Guo, S. Bai, Y. Ye, L.'. Zhu, and S. Li, “A new strategy for high-value reutilization of recycled carbon fiber: Preparation and friction performance of recycled carbon fiber felt-based C/C-SiC brake pads," Ceramics International, vol. 45, no. 13, pp. 16545-16553, 2019.

[94] M. A. Maleque, A. Atiqah, R. J. Talib, and H. Zahurin, "New natural fibre reinforced aluminium composite for automotive brake pad," International Journal of Mechanical and Materials Engineering, vol. 7, no. 2, pp. 166-170, 2012.

[95] S. K. Kancharla, Effect of humidity and testing strategy on friction performance of model brake pads containing nano-additives, [M.S. thesis], Southern Illinois University Carbondale, 2018.

[96] L. Klapiszewski, A. Jamrozik, B. Strzemiecka, D. Matykiewicz, A. Voelkel, and T. Jesionowski, "Activation of magnesium lignosulfonate and kraft lignin: influence on the properties of phenolic resin-based composites for potential applications in abrasive materials," International Journal of Molecular Sciences, vol. 18, no. 6, p. 1224, 2017.

[97] A. Sharma, A. Chouhan, L. Pavithran, U. Chadha, and S. Kumaran Selvaraj, "Implementation of LSS framework in automotive component manufacturing: a review, current scenario and future directions," Materials Today: Proceedings, vol. 46, pp. 7815-7824, 2021. 
[98] B. C. Goo, "Development and characterization of C/C-SiC brake disc," Materials and Manufacturing Processes, vol. 31, no. 8, pp. 979-988, 2016.

[99] T. Policandriotes and P. Filip, "Effects of selected nanoadditives on the friction and wear performance of carboncarbon aircraft brake composites," Wear, vol. 271, no. 9-10, pp. 2280-2289, 2011.

[100] X. R. Zhang, X. Q. Pei, Q. H. Wang, T. M. Wang, and S. B. Chen, "The friction and wear properties of carbon nanotubes/graphite/carbon fabric reinforced phenolic polymer composites," Advanced Composite Materials, vol. 24, no. sup1, pp. 147-159, 2015.

[101] R. Abhik and V. Umasankar, "Evaluation of properties for hybrid Al-SiC-carbon fiber reinforced metal matrix composite for brake pads," in 2016 International Conference on Electrical, Electronics, and Optimization Techniques (ICEEOT), pp. 789-793, Chennai, India, 2016.

[102] M. G. Faga, E. Casamassa, V. Iodice, A. Sin, and G. Gautier, "Morphological and structural features affecting the friction properties of carbon materials for brake pads," Tribology International, vol. 140, article 105889, 2019.

[103] M. R. Wiesner, G. V. Lowry, P. Alvarez, D. Dionysiou, and P. Biswas, "Assessing the risks of manufactured nanomaterials," Environmental Science \& Technology, vol. 40, no. 14, pp. 4336-4345, 2006.

[104] G. V. Lowry and E. A. Casman, "Nanomaterial transport, transformation, and fate in the environment," in Nanomaterials: Risks and Benefits (pp. 125-137), Springer, Dordrecht, 2009.

[105] D. Mohanta, S. Patnaik, S. Sood, and N. Das, "Carbon nanotubes: evaluation of toxicity at biointerfaces," Journal of Pharmaceutical Analysis, vol. 9, no. 5, pp. 293-300, 2019.

[106] T. Thurnherr, C. Brandenberger, K. Fischer et al., "A comparison of acute and long-term effects of industrial multiwalled carbon nanotubes on human lung and immune cells in vitro," Toxicology Letters, vol. 200, no. 3, pp. 176-186, 2011.

[107] J. Du, S. Wang, H. You, and X. Zhao, "Understanding the toxicity of carbon nanotubes in the environment is crucial to the control of nanomaterials in producing and processing and the assessment of health risk for human: a review," Environmental Toxicology and Pharmacology, vol. 36, no. 2, pp. 451-462, 2013. 